Atmos. Chem. Phys. Discuss., 9, 3113-3166, 2009

www.atmos-chem-phys-discuss.net/9/3113/2009/

(C) Author(s) 2009. This work is distributed under

the Creative Commons Attribution 3.0 License.

This discussion paper is/has been under review for the journal Atmospheric Chemistry and Physics (ACP). Please refer to the corresponding final paper in $A C P$ if available.

\title{
High-ozone layers in the middle and upper troposphere above Central Europe: strong import from the stratosphere over the Pacific Ocean
}

T. Trickl ${ }^{1}$, N. Bärtsch-Ritter ${ }^{2}$, H. Eisele ${ }^{1}$, M. Furger $^{2}$, R. Mücke ${ }^{1}$, and A. Stohl ${ }^{3, *}$

${ }^{1}$ Forschungszentrum Karlsruhe, Institut für Meteorologie und Klimaforschung (IMK-IFU), Kreuzeckbahnstr. 19, 82467 Garmisch-Partenkirchen, Germany

${ }^{2}$ Paul Scherrer Institut, Labor für Atmosphärenchemie, 5232 Villigen PSI, Switzerland

${ }^{3}$ Lehrstuhl für Ökoklimatologie, Technische Universität München, Am Hochanger 13, 85354 Freising-Weihenstephan, Germany

now at: Norwegian Institute for Air Research, P.O. Box 100, Instituttveien 18,

2027 Kjeller, Norway

Received: 8 September 2008 - Accepted: 30 December 2008 - Published: 30 January 2009

Correspondence to: T. Trickl (thomas.trickl@imk.fzk.de)

Published by Copernicus Publications on behalf of the European Geosciences Union.

ACPD

9, 3113-3166, 2009

High-ozone layers in the middle and upper troposphere

T. Trickl et al.

Title Page

Abstract

Introduction

Conclusions

Tables References

Figures

14

I

4

Back

Close

Full Screen / Esc

Printer-friendly Version

Interactive Discussion 


\section{Abstract}

Very dry high-ozone layers have been repeatedly observed with the ozone lidar in Garmisch-Partenkirchen (Germany) starting one or two days after the onset of highpressure periods during the warm season. These episodes have been analysed by 5 trajectory calculations and extended simulations with the FLEXPART particle dispersion model. Mixed contributions from the stratosphere over the Pacific Ocean and the boundary layers of East Asia and North America were found. The stratospheric influence is mostly dominating and caused by a rather shallow transfer from the stratosphere into these rapid upper- and mid-tropospheric air streams. The considerable vertical extent of these layers and peak ozone mixing ratios between 80 and $150 \mathrm{ppb}$ suggest an important mechanism for stratosphere-to-troposphere transport.

\section{Introduction}

In recent studies of trans-Atlantic transport we repeatedly detected very dry air masses above $4 \mathrm{~km}$ with peak ozone mixing ratios of 80 to $150 \mathrm{ppb}$ both in lidar measurements Garmisch-Partenkirchen (Germany) and vertical profiles extracted from the MOZAIC (Measurements of Ozone by Airbus In-Service Aircraft (Marenco et al., 1998)) data base. We presented three of these cases in a recent publication (Trickl et al., 2003). Some of these layers contained aerosols indicating the presence of air from a remote planetary boundary-layer (PBL), most likely admixed to these ozone-rich air streams in the vicinity of frontal systems. Despite this contribution from the North American PBL the backward trajectories indicate a strong additional, upper-tropospheric component from the North Pacific that is likely to be responsible for the low humidity. These ozonerich layers, in part as thick as $6 \mathrm{~km}$, may strongly influence the free-tropospheric ozone budget.

25 Similar observations of such a very dry air stream were, e.g., reported on by Prados et al. (1999), Bithell et al. (2000), and by Law et al. (2001) (see also Penkett et
High-ozone layers in the middle and upper troposphere

T. Trickl et al.

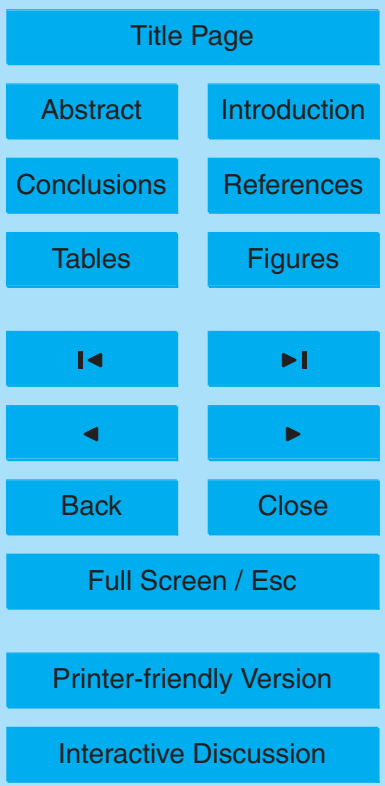


al., 2004). Prados et al. (1999) examined a post-frontal air stream in the vicinity of Bermuda advecting up to almost $90 \mathrm{ppb}$ of ozone and almost $250 \mathrm{ppb}$ of $\mathrm{CO}$ in the altitude range between 3.5 and $6.3 \mathrm{~km}$. A trajectory shown for this layer does not reveal any contact with the PBL and ends over the Pacific at pressures below 500 mbar. Mix5 ing of different air streams was postulated. The observations of Penkett et al. (2004) were made during a flight in the vicinity of a hurricane over the Atlantic Ocean. Up to $100 \mathrm{ppb}$ of ozone were found, co-existing with up to $120 \mathrm{ppb}$ of $\mathrm{CO}$ that is above the local background level of about $80 \mathrm{ppb}$ (see also Val Martin et al., 2006). The most polluted layer was traced back to the boundary layer (PBL) in the south-eastern United 10 States (US). However, the trajectories published for this case suggest mixing with an upper-tropospheric air stream that, unfortunately, cannot be traced back by the trajectories beyond the central US within the seven days of trajectory paths displayed. Newell et al. (1999), by analysing vertical profiles from the MOZAIC data base, found that atmospheric layers are most frequently associated with an increase in ozone and 15 a simultaneous decrease in water vapour. Typical altitudes are $6 \mathrm{~km}$ and the average thickness of layers showing this kind of anti-correlation is of the order of $1 \mathrm{~km}$.

The occurrence of high ozone values in these dry layers suggests the presence of a stratospheric component. But, obviously, the mechanism of stratospheric import leading to such high ozone values in such wide layers must differ from the deep intrusions most commonly observed at our observational site (e.g., Reiter et al., 1971; Eisele et al., 1999; Stohl and Trickl, 1999; Trickl et al., 2003; Zanis et al., 2003; Trickl et al., 2009a). These deep intrusions are mostly confined to rather narrow air tongues with decreasing ozone mixing ratios as the layers approach the ground, to a major extent as a consequence of a horizontal divergence of the air parcels. The typical ozone mixing ratios measured in stratospheric streamers at the nearby Zugspitze summit (2962 m a.s.I.) range just between 60 and $80 \mathrm{ppb}$. There is no way to explain the high mid- and upper-tropospheric ozone concentrations in a layer several kilometres thick by an admixture of such a diluted air mass.

Potential source regions are the atmosphere above the Pacific Ocean and East Asia

High-ozone layers in the middle and upper troposphere

T. Trickl et al.

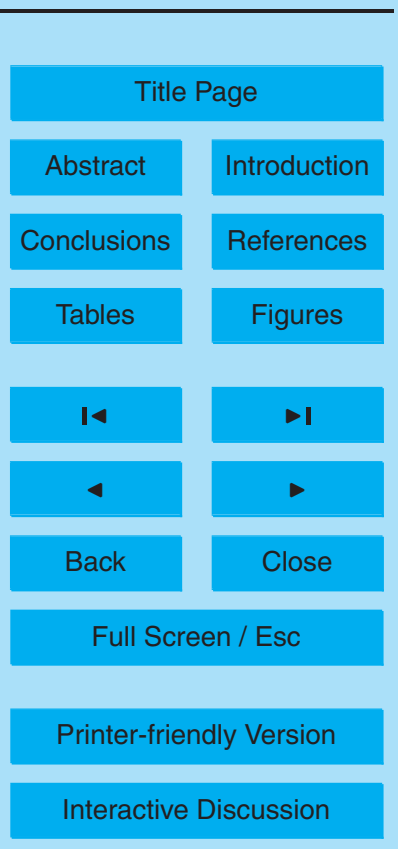


where frequent and pronounced stratospheric air intrusions may occur (Austin and Midgley, 1994; James et al., 2003; Sprenger et al., 2003). Cooper et al. (2005) report on two strong intrusions in 2004 that even reached Hawaii and led to the observation of 81 and $115 \mathrm{ppb}$ ozone at the Mauna Loa Observatory (3400 ma.s.I.), respectively.

5 The second event (10 March 2004) even reached the sea level, $60 \mathrm{ppb}$ were recorded at Honolulu. This is particularly remarkable since, at least over the continent, stratospheric intrusions rarely proceed to the ground (e.g., Reiter, 1987; Davis and Schuepbach, 1994; Elbern et al., 1997; Eisele et al., 1999; Schuepbach et al., 1999).

Cooper et al. (2004b) also describe that air from a dry intrusion may be mixed into the 10 ascending air streams of adjacent warm conveyor belts (WCBs). In their case study (May 2002) they find that roughly half of the stratospheric component of the dry air stream was dispersed into the upwind and downwind WCBs over the Pacific Ocean. The stratospheric air mass was then lifted back to the upper troposphere and lower stratosphere where it passed over North America and the Atlantic at rather constant altitude. Quite differently, trans-Pacific transport may also occur almost entirely in the upper troposphere. Very rapid trans-Pacific transport of radon-rich air (life time 3.8 days) in the upper troposphere was reported on by Kritz et al. (1990). Liang et al. (2007) observed a case in which subsequent trans-Pacific and trans-North-American transport of an ozone-rich air mass took place exclusively at high altitudes. The entire passage from the West Pacific to the North American east coast occurred within about eight days. A significant ozone enhancement in the upper troposphere above midlatitude North America due to import from the stratosphere was concluded by Cooper et al. (2006).

The almost zonal propagation of air masses to the east at high altitudes described 25 by Cooper et al. $(2004 a, b)$ and Liang et al. (2007) exhibits some similarity with that reported on by Trickl et al. (2003). A very intriguing idea for explaining the high ozone values in the dry air streams observed above Garmisch-Partenkirchen would be that of shallow intrusions directly injecting ozone into the jet stream over the Pacific Ocean. Sprenger et al. (2003) locate a maximum in occurrence (partly exceeding a relative

High-ozone layers in the middle and upper troposphere

T. Trickl et al.

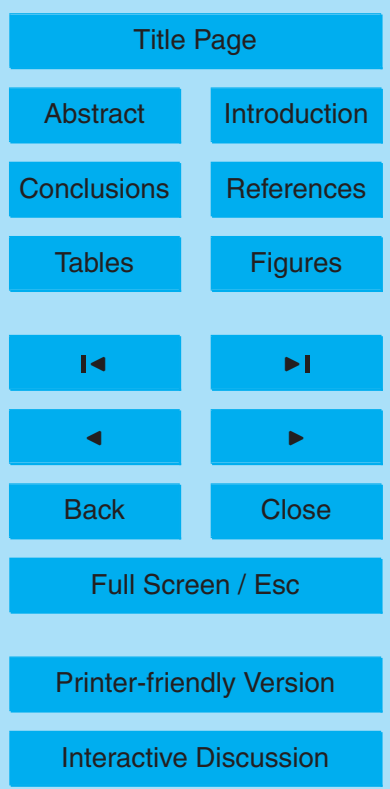

Interactive Discussion 
frequency of $30 \%$ ) of shallow intrusions between North Africa and the Pacific Ocean between $30^{\circ}$ and $40^{\circ} \mathrm{N}$.

High free-tropospheric ozone concentrations could, in part, also be related to air pollution export from East Asia. The subtropical western Pacific is one of the two 5 most important inflow regions for WCBs in the Northern Hemisphere (Stohl, 2001). Cooper et al. (2004a, b) emphasize the role of WCBs in transporting Asian air pollution across the Pacific. As mentioned above they found that these air streams may merge with stratospheric air (see also Liang et al., 2007). As the lofted layers enter North America they stay in the middle and upper troposphere and are rapidly transported to 10 the Atlantic.

Coherent bundles of backward trajectories staying in the middle and upper troposphere between the Pacific Ocean and Garmisch-Partenkirchen have been quite frequently observed, also in other investigations. However, these trajectories had never been followed back beyond a few degrees west of North America. In this paper, we analyse the long-range transport pathways leading to the dry layers described by Trickl et al. (2003) in some more detail, motivated by the idea of a potentially strong stratospheric contribution to tropospheric ozone. Within the German ATMOFAST (Atmospheric Long-range Transport and its Impact on the Trace-gas Concentrations over Central Europe; ATMOFAST, 2005) project backward model simulations were extended to fifteen and even twenty days in order to provide the missing origins of the anomalously high ozone values. We also discuss two additional cases from the particularly dense lidar measurements in Garmisch-Partenkirchen in 2001. We present this large number of analogous cases in order to underline the importance and reproducibility of our findings, but also in order to show the differences in appearance.

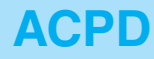

9, 3113-3166, 2009

High-ozone layers in the middle and upper troposphere

T. Trickl et al.

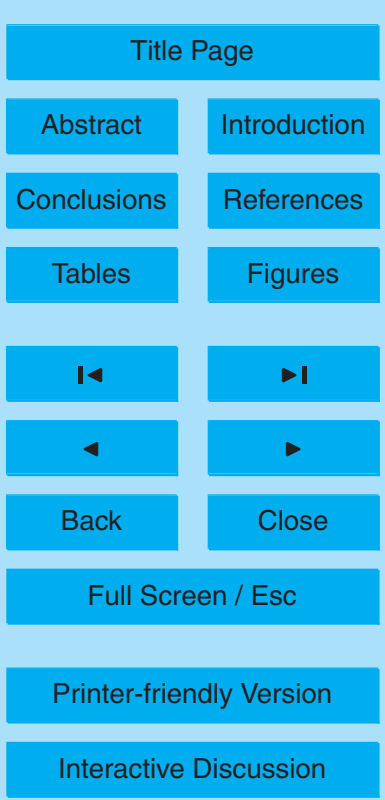




\section{Methods}

\subsection{Measurements}

In this study we use data from measurements with two lidar systems at IMK-IFU $\left(47^{\circ} 28^{\prime} 37^{\prime \prime} \mathrm{N}, 11^{\circ} 3^{\prime} 52^{\prime \prime} \mathrm{E}, 730 \mathrm{~m}\right.$ a.s.I.). The tropospheric ozone lidar ( $740 \mathrm{~m}$ a.s.I.) was 5 completed in its first version in 1990 (Kempfer et al., 1994) and upgraded in 1994 and 1995 (Eisele and Trickl, 1996, 2005). It has a unique vertical range between $0.2 \mathrm{~km}$ and roughly $15 \mathrm{~km}$ above the ground, features low uncertainties of about $\pm 3 \mathrm{ppb}$ in the lower troposphere and $\pm 6 \mathrm{ppb}$ (under optimum conditions) in the upper troposphere. The upper-tropospheric performance may be degraded in the presence of high lowertropospheric ozone concentrations absorbing a lot of the ultraviolet laser emission and by enhanced sky light in summer, in particular in the presence of clouds. The vertical resolution is dynamically varied between $50 \mathrm{~m}$ and a few hundred metres, depending on the signal-to-noise ratio that decreases with altitude. The lidar has been used in numerous investigations focussing on atmospheric transport (e.g., Eisele et al., 1999; Stohl and Trickl, 1999; Seibert et al., 2000; Carnuth et al., 2002; Roelofs et al., 2003; Trickl et al., 2003; Zanis et al., 2003).

Aerosol backscatter coefficients were taken from measurements with the big aerosol lidar at IMK-IFU (730 ma.s.I.), a primary instrument of the Network of the Detection of Atmospheric Composition Change (NDACC). This system was originally built in 1973, based on a ruby laser, and has been continually used for measurements of stratospheric aerosol since 1976 (e.g., Jäger, 2005; Deshler et al., 2006; Fromm et al., 2008). The lidar was converted to a spatially scanning system in the early 1990 s for additional investigation of contrails (Freudenthaler et al., 1994) and, for the routine measurements, has been operated at the wavelength of $532 \mathrm{~nm}$ ever since. The mea-

surements discussed here were either routine early-night stratospheric measurements (vertical pointing) or campaign measurements (May 1999, at elevation angles mostly of 25 to 45 degrees in order to improve the coverage of the PBL). For an optimum signal-to-noise ratio in the upper troposphere we evaluated only measurements for the

High-ozone layers in the middle and upper troposphere

T. Trickl et al.

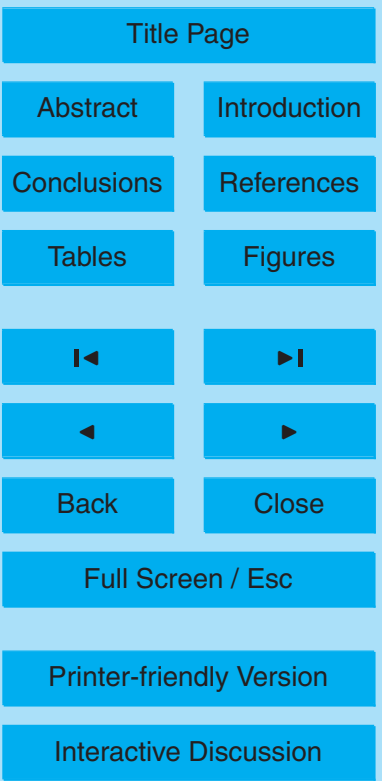


highest angles.

In addition, in-situ data from the monitoring stations Garmisch-Partenkirchen (745 ma.s.I., at IMK-IFU), Wank (1780 ma.s.I.) and Zugspitze (2962 ma.s.I.) have been used, in particular ozone, ${ }^{7} \mathrm{Be}$, carbon monoxide, $\mathrm{NO}_{\mathrm{y}}$ and relative humidity.

5 These stations are located at distances of $8 \mathrm{~km}$ and less from the lidar.

In May 1999, a radiosounding system was operated at Krün $\left(47^{\circ} 30^{\prime} 38^{\prime \prime} \mathrm{N}\right.$, $11^{\circ} 16^{\prime} 52^{\prime \prime} \mathrm{E}, 876 \mathrm{~m}$ a.s.I.), $17 \mathrm{~km}$ roughly to the east of IMK-IFU, by a team of the Paul-Scherrer Institute (PSI, Switzerland) as a contribution to the VOTALP "Munich" field campaign (VOTALP II, 2000). For the study presented here this system yielded

10 important complementary information for the lidar and station measurements in the Garmisch-Partenkichen area. A VIZ W-9000 LORAN-C radiosonde was used (http: //www.sippican.com). Each sounding provided the standard meteorological parameters pressure, temperature, relative humidity, and horizontal wind vector as a function of altitude. Relative humidity was measured with a fast-response carbon hygristor. Ten of

15 the sondes were equipped with an additional ozone sensor, a Model $\mathrm{Z} \mathrm{ECC} \mathrm{O}$ sonde of EN-SCI Corporation, Boulder, Colorado, that uses an electrochemical concentration cell to measure the ozone concentration (Komhyr, 1969). Sonde measurements were performed from 26 to 28 May 1999, with a total of 16 ascents in irregular intervals during daylight hours.

As in the preceding publications (Stohl and Trickl, 1999; Trickl et al., 2003) we use ozone and water-vapour data from the MOZAIC (Measurements of Ozone and Water Vapor by Airbus In-Service Aircraft) project (Marenco et al., 1998) that have been routinely made onboard five commercial airliners, again for the May-1996 case (see below). This dataset provides daily vertical profiles over Europe, transects at cruising altitude over the North Atlantic and occasional vertical profiles at various locations over North America.

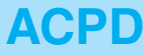

9, 3113-3166, 2009

High-ozone layers in the middle and upper troposphere

T. Trickl et al.

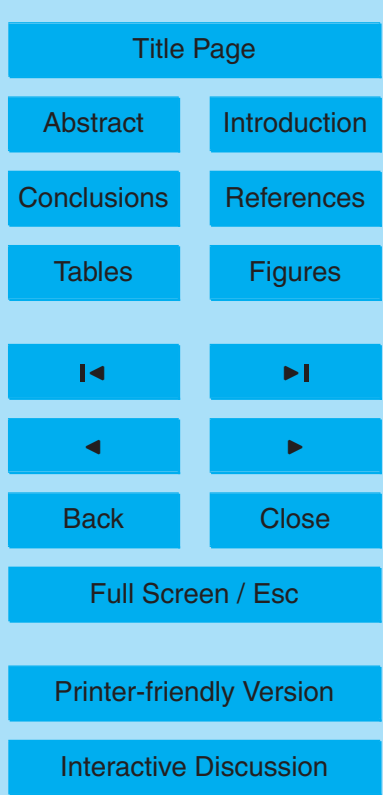


The transport pathways and source regions were identified by calculations with the FLEXTRA trajectory model (Stohl et al., 1995; Stohl and Seibert, 1998) and the FLEXPART particle dispersion model (Stohl et al., 1998, 2005; Stohl and Thomson, 1999). 5 In this study, ten-day backward trajectories were used as the primary tool to visualize the altitude of confined air streams that stay in the middle and upper troposphere.

In principle, trajectory analyses are problematic for the investigation of very long transport pathways due to the neglect of dispersion as a result of turbulence and convection and a decreasing horizontal density (coverage) as one goes backward in time.

10 As a consequence backward options of the FLEXPART model have been developed and successfully applied (e.g., Stohl et al., 2003; Trickl et al., 2003; Huntrieser et al., 2005) within several subprojects of the German atmospheric research programme Atmosphärenforschung 2000 (AFO 2000, 2005). The backward plumes yield a much more complete picture of where the air masses come from. The first product is 15 a column-integrated emission sensitivity that is proportional to the residence time of the particles over a unit area. Longer residence times mean a higher sensitivity to the local emissions. The emission sensitivities are also displayed for selected altitudes. Altitudes of $500 \mathrm{~m}$ and less, as used in the investigations presented here, are all representative of the PBL and, thus, can identify areas of potential emission uptake from the surface. Turbulence and convection in the PBL as well as moist convection throughout the atmosphere are accounted for in the FLEXPART model (Stohl et al., 2005). By folding the emission sensitivity with emission fluxes from appropriate inventories the source regions may be highlighted. For the work presented here the EDGAR 3.2 fasttrack inventory for the year 2000 (Olivier and Berdowski, 2001) has been used. For 25 large parts of North America, the regional inventory of Frost et al. (2006) was used in the most recent twenty-day simulations (see below).

The first backward analyses (for Cases 1, 2 and 4 in Sect. 3), as already presented at several conferences (e.g., Jäger et al., 2004; Kanter et al., 2004), were started in
High-ozone layers in the middle and upper troposphere

T. Trickl et al.

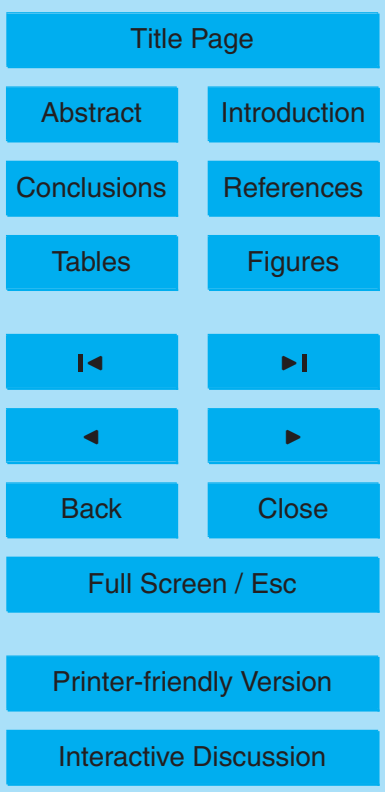


specific time-altitude boxes over Garmisch-Partenkirchen and extended over fifteen days. This was found to be sufficient to identify even contributions from East Asia, as a consequence of the high speed and coherence of these air streams. In addition, these calculations provided a special feature not available in the later analyses de5 scribed a few lines below: They highlight the areas where an altitude of $12000 \mathrm{~m}$ was reached, i.e., where stratosphere-to-troposphere transport (STT) might have occurred at sufficiently high latitudes.

In order to create a better overlap with East Asia and to identify potential additional Asian contributions not accessible within fifteen days, further simulations, extended 10 to twenty days, were added for selected start times above Garmisch-Partenkirchen. These simulations also include a full "retroplume analysis" as described by Stohl et al. (2002). Particles were released in 250-m bins above Garmisch-Partenkirchen, up to $12 \mathrm{~km}$ a.s.I. Both the mean horizontal and vertical position of up to five clusters of the backward plume for a 250-m bin is given and the fraction of the PBL. The positions of the individual clusters are marked by a circle with a radius proportional to the number of particles in the respective cluster. The colour of these circles represent their altitude and a number gives the backward time in days. The centroid of the retroplume is also displayed by a trajectory, but as the plumes get complex backward in time the centroid may not be very representative of the true position of the most significant part of the 20 plume.

The twenty-day calculations also yield vertical distributions of emissions from the different continents based on the EDGAR 3.2 inventory. Also the fraction of particles with contact with the PBL or the stratosphere is given for each travel day. The threshold condition for the stratosphere was chosen as a potential vorticity of 2 pvu polewards from $30^{\circ}$. The thermal tropopause was applied in the tropics. In addition, images of the sensitivity columns, PBL "footprints" and emission-tracer source regions are provided.

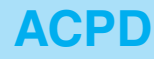

9, 3113-3166, 2009

High-ozone layers in the middle and upper troposphere

T. Trickl et al.

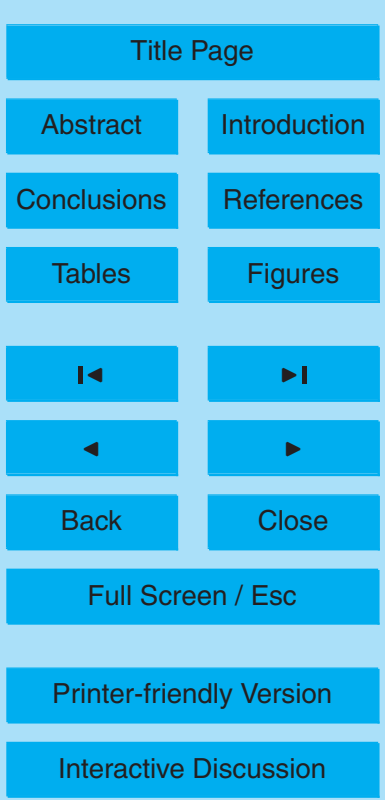




\section{Results}

\subsection{Case 1: 31 May 1996}

The measurements with the ozone lidar in Garmisch-Partenkirchen between 29 May and 1 June 1996, have been intensively discussed previously. They were carried out 5 to study a predicted stratospheric air intrusion (Eisele et al., 1999) and have been the subject of several modelling efforts including model validation and intercomparison (Feldmann et al., 1999; Stohl et al., 2000; Cristofanelli, 2003; Meloen et al., 2003). This time series yielded the first evidence of significant trans-Atlantic transport of ozone (Stohl and Trickl, 1999 (Sect. 5); Trickl et al., 2003). High-ozone layers of trans-Atlantic origin were observed above $4 \mathrm{~km}$ almost during the entire period. The North American ozone contributions were concentrated mostly above $8 \mathrm{~km}$ and in a layer that gradually descended to $4 \mathrm{~km}$. The most important source regions were Texas, Mexico and, to some extent, also the south-western United States (US). Some uncertainty exists concerning the impact of a large convective cell in the frontal system lifting the air masses to the mid-troposphere. Most importantly, significant stratospheric air inflow into the troposphere could be excluded over North America and the Atlantic.

A very special situation was found for 31 May. The model simulations showed some North American influence in the upper troposphere and in the descending layer on all days (see above), but, on 31 May, they did not yield any evidence of a significant PBL contribution in a high-ozone layer between 5 and $7 \mathrm{~km}$ (later $8 \mathrm{~km}$ ) during a major part of this day. An example of an ozone profile from this period, measured at 19:00 CET (Central European Time $(\mathrm{CET})=\mathrm{UTC}+1 \mathrm{~h}$ ), is shown in Fig. 1 together with a MOZAIC ozone and a humidity profile for Frankfurt several hours earlier (same profiles as in the preceding publication). These two measurements show the best mutual agreement on that afternoon, which reflects the fact Garmisch-Partenkirchen was approximately downwind of Frankfurt (distance: roughly $330 \mathrm{~km}$ ) and the ascent route towards the Netherlands. The air mass was very dry indicating that a potential stratospheric air admixture from beyond North America could have created the high ozone values. The

High-ozone layers in the middle and upper troposphere

T. Trickl et al.

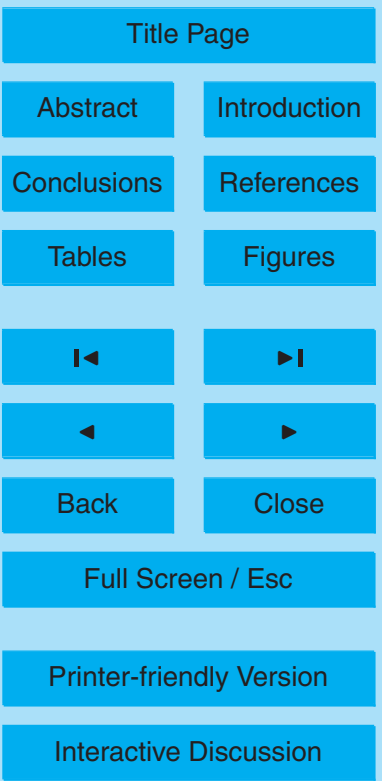


considerable width of the layer suggested a potentially strong contribution to STT and, thus, an extension of the analysis.

The backscatter profiles for $313 \mathrm{~nm}$ ("off" wavelength of the ozone lidar, not shown) indicate the presence of aerosol above $8 \mathrm{~km}$ in some of the measurements on 31 May. 5 Due to the strong background noise from Rayleigh backscattering at $313 \mathrm{~nm}$ these structures just slightly exceed the noise. A better contrast exists for the aerosol lidar due to the lower Rayleigh background at $532 \mathrm{~nm}$. The NDACC measurement on 31 May was made after the onset of darkness (as usual), i.e., next to the end of the period with the highest ozone values. Small aerosol structures observed between 7.3 and $109 \mathrm{~km}$ and, again, above $9 \mathrm{~km}$ (including a cirrus spike at $12.2 \mathrm{~km}$ ) indicate long-range advection from a remote PBL. No aerosol is seen in the region between 4 and $7.3 \mathrm{~km}$ that includes the 95-ppb ozone hump, in agreement with our earlier conclusion of an absence of a North American component.

In order to identify the origin of the elevated ozone concentrations, fifteen-day FLEX15 PART backward ("retroplume") simulations were carried out for two altitude ranges above Garmisch-Partenkirchen ( 5 to $7 \mathrm{~km}$ and 7 to $10 \mathrm{~km}$ a.s.I.) and a major part of 31 May (see Figs. 2 and 3). The emission sensitivities are shown for the PBL (also folded with $\mathrm{NO}_{\mathrm{x}}$ emissions in the third panel) and $12000 \mathrm{~m}$, as well as integrated over the entire column. $12000 \mathrm{~m}$ is taken as a crude guess for a potential transition of air from the stratosphere into the troposphere.

The simulation for the altitude range between 5 and $7 \mathrm{~km}$ (Fig. 2) confirms the absence of a significant PBL contribution in this layer. This suggests a dominating stratospheric influence. In agreement with our earlier findings no significant stratospheric influence is seen over North America and the Atlantic (Trickl et al., 2003). This is quite different over the Pacific. The 12000-m panels of both Figs. 2 and 3 show clear sensitivity signatures over the West Pacific between roughly $30^{\circ}$ and $60^{\circ} \mathrm{N}$. Some of the high-altitude air mass travels backward even once around the globe within fifteen days. $12 \mathrm{~km}$ is not necessarily representing the tropopause at low latitudes. However, a rather big intrusion is seen in Fig. 3 between Kamchatka and about $40^{\circ} \mathrm{N}, 180^{\circ} \mathrm{E}$. The

High-ozone layers in the middle and upper troposphere

T. Trickl et al.

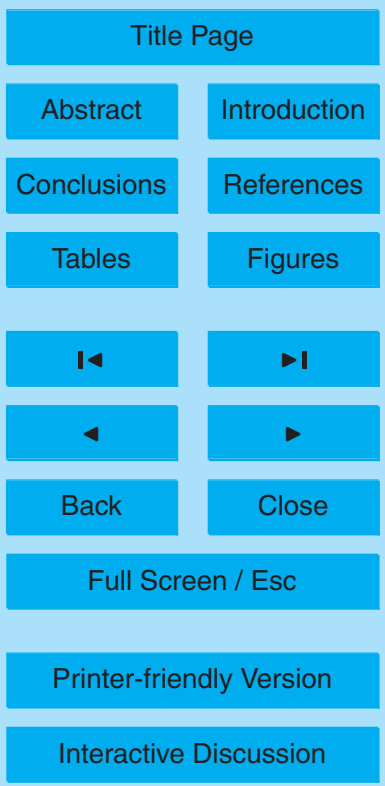

Interactive Discussion 
existence of this intrusion was verified also by forward trajectory calculations initiated over that area. It was found that the trajectories mostly stay above $5 \mathrm{~km}$ and proceed towards North America and, in part, Europe.

This interpretation did not change when we recently extended these simulations to 5 twenty days, in particular for the time of the measurement shown in Fig. 1. As described in Sect. 2.2 the new analysis tools even allowed us to generate time-longitude sections and probabilities for stratospheric input or PBL contact (Fig. 4). The second panel in Fig. $4(5500$ to $5750 \mathrm{~m})$ shows a pronounced stratospheric influence for the earliest days: $12 \%$ of stratospheric influence can be converted into an ozone enhancement by 10 up to $60 \mathrm{ppb}$, assuming ozone values of up to $0.5 \mathrm{ppm}$ within the first few kilometres above the tropopause as seen in many measurements.

In the upper troposphere (Fig. 3 and lowest panel in Fig. 4) PBL contributions coexisted with stratospheric contributions. The air flow in this altitude range is much faster, with transport times between the Pacific and Garmisch-Partenkirchen of less than ten days, as already revealed by our earlier trajectory analysis (Trickl et al., 2003). Pronounced contributions from various polluted regions around the Gulf of Mexico, Mexico City and from southern California are seen. Very high ozone mixing ratios are reported for Mexico City in May 1996. The local station network reports peak values between 180 and almost 230 ppb between 12 and 18 May, 125 ppb on 19 May, and between 150 and almost 270 ppb until the end of May (http://www.sma.df.gob.mx/ simat/home_base.php). Again, Asian contributions are almost absent. This can also be seen from the calculated vertical distribution of the emissions from the different continents reaching Garmisch-Partenkirchen shown in Fig. 5.

\subsection{Case 2: May 1999}

25 The ozone series between 26 May and 30 May 1999, showed the longest persisting high mixing ratios ever observed with the ozone lidar in the middle and upper troposphere above Garmisch-Partenkirchen (Trickl, 2003). The ozone mixing ratio above $4 \mathrm{~km}$ reached values between 80 and roughly $150 \mathrm{ppb}$. The analysis showed sources

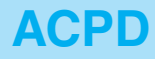

9, 3113-3166, 2009

High-ozone layers in the middle and upper troposphere

T. Trickl et al.

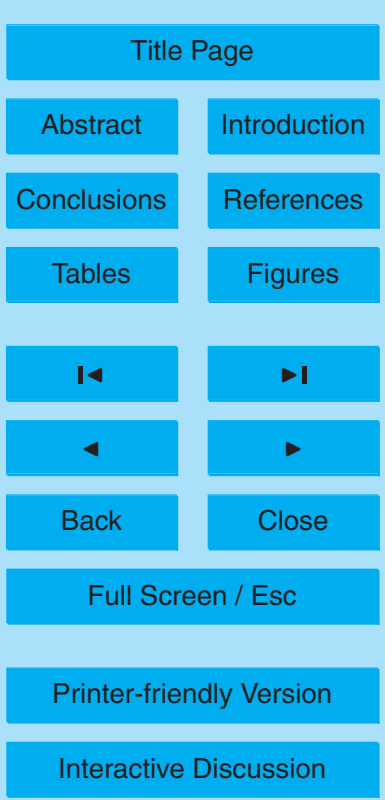


in the North American PBL, but also a some strong, almost horizontal high-altitude flow from the Pacific to Europe. On 27 May, 70 to $80 \mathrm{ppb}$ were observed also below $4 \mathrm{~km}$ and ascribed to direct input from the eastern US, one of the rare cases in which this has led to a pronounced rise in ozone at the Zugspitze summit (see Stohl et al., 2003; 5 Huntrieser et al., 2005 for another example). The $\mathrm{NO}_{\mathrm{y}}$ mixing ratios at the nearby Wank station (1780 m a.s.I.) were just between 1 and 2 ppb which indicates a low European contribution to this air mass.

During that period a VOTALP II field campaign took place, devoted to the investigation of the transport of the Munich plume into the Alps, in particular in the Loisach and 10 Isar valleys (VOTALP II, 2000). The mobile sonde station, operated by the PSI team at Krün between 26 and 28 May (see Sect. 2.1), yielded similar ozone profiles as the lidar, the only major difference being vertical displacements due to orographic lifting of the sonde. In addition, frequent measurements with the big aerosol lidar were made during this field campaign, yielding information on potential contributions from remote boundary layers. Due to the availabilty of all these complementary measurements we discuss this period in particular detail. In the following we present four examples from the period during which all system were operated.

After a final frontal passage on 23 May a long high-pressure zone formed that extended from the region south of Newfoundland to $30^{\circ} \mathrm{E}$ on 24 May. A stratospheric intrusion is expected to occur during the transition to high pressure. However, there is only a slight indication of an intrusion in the Zugspitze ozone and humidity data. We assume that the intrusion was shifted to the east in the rapid eastward air flow north of the Alps.

Due to the preparations for the field campaign no lidar measurements were made on the first two days of this high-pressure period. The measurements were started two days later, in the early afternoon of 26 May, and immediately showed the high-ozone layer that was observed over many days. Figure 6 a shows one example of soundings on 26 May at about 16:00 CET, when the first PSI ozone sonde was launched. The principal agreement between lidar and sonde in that obviously spatially rather inho-

High-ozone layers in the middle and upper troposphere

T. Trickl et al.

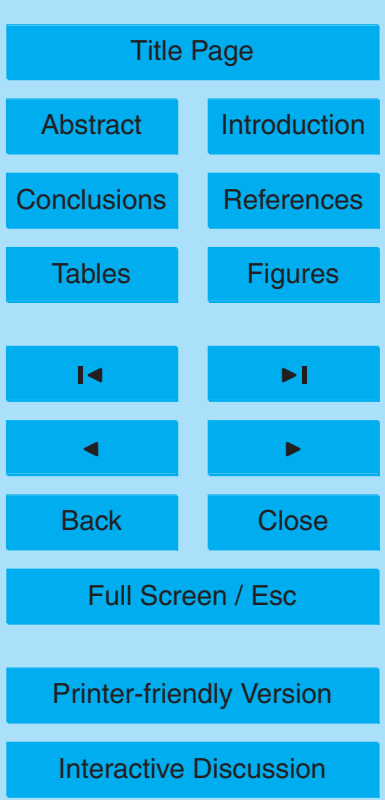

Interactive Discussion 
mogeneous ozone plume is not perfect, but acceptable. The lidar data are confirmed up to $3 \mathrm{~km}$ by the measurements at the nearby local monitoring stations, whereas the sonde should have departed more to the east. For the range above $5 \mathrm{~km}$ some uncertainty and range limitation in the daytime measurements was caused during the entire 5 field campaign by a small light leak in the receiver box. Above $4 \mathrm{~km}$ elevated ozone is correlated with low humidity and, in part, with aerosol. Both the ozone lidar and the PSI data, unfortunately, end just above $7 \mathrm{~km}$. However, the aerosol lidar detected significant traces of particles between $7.3 \mathrm{~km}$ and $11.7 \mathrm{~km}$, the latter value agreeing with the tropopause levels determined by the Munich radiosonde $(11.6 \mathrm{~km}$ at $12: 00$ UTC 10 and $11.8 \mathrm{~km}$ at 24:00 UTC). A closer look at the trajectories calculated for our earlier study (Trickl et al., 2003) suggests that at least some of this aerosol could be associated with an ascending air stream from the mid-west of the US. There, 60 to $80 \mathrm{ppb}$ of ozone were observed that do not fully explain explain the values at the upper end of the sounding range. However, there is also a thick, almost horizontal trajectory bundle above $5 \mathrm{~km}$ leading backward to the west coast of North America suggesting potential additional sources of ozone.

Figure $6 \mathrm{~b}$ and $\mathrm{c}$ show very high ozone and aerosol values on 27 May 1999, correlated with low relative humidities down to $5 \%$ (please, note in Fig. $6 \mathrm{c}$ the vertical offset of the lidar and the sonde data above $3.3 \mathrm{~km}$ ). The aerosol peaks for the 532 $20 \mathrm{~nm}$ measurements reach almost $10^{-5}\left(\mathrm{~m} \mathrm{sr}^{-1}\right.$, which is rather remarkable for the free troposphere and corresponds to a visual range of less than $10 \mathrm{~km}$. Such values are almost one order of magnitude higher than typical values for aerosol structures related to intercontinental transport, even in fire plumes from the US observed during strong fire years (see Sect. 4). The analysis by Trickl et al. (2003) showed mixed input from different parts of the US in a rather horizontal air stream, but, again, a number of middle and upper-tropospheric trajectories indicate a contribution to the high-ozone air mass from beyond North America.

The fourth example (Fig. 6d) is from a period on 28 May (not analysed in our earlier publication) between an early-morning thunderstorm and rain in the afternoon. There
High-ozone layers in the middle and upper troposphere

T. Trickl et al.

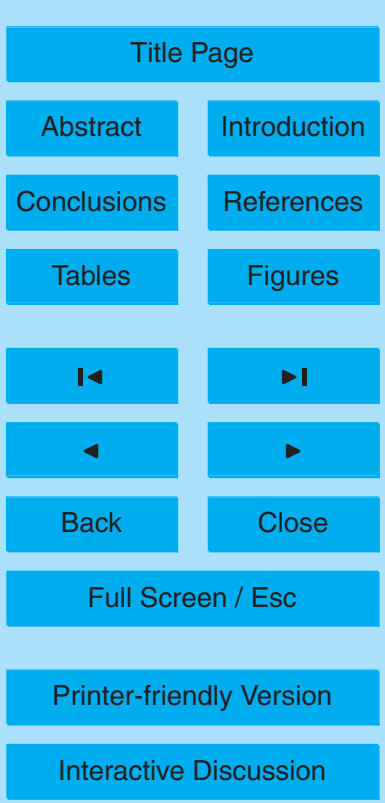


was much less aerosol, but, still, the ozone values were high and the corresponding humidity was low. Before the thunderstorm the ozone values had reached almost $150 \mathrm{ppb}$ (03:00 CET). There is not much indication of a PBL contact over North America within the ten days of trajectory calculation time. Most trajectories end over the subtropical 5 Atlantic to the north-east or east of Cuba, at altitudes between roughly 3 and $9 \mathrm{~km}$. Those in the uppermost troposphere, again, extend from this area further to the west and reach the Pacific.

As a first step to extend the analysis, a fifteen-day FLEXPART backward simulation was carried out for the high-ozone layer between 5 and $9 \mathrm{~km}$ on 27 May (Fig. 7). The 10 result looks similar to those in Figs. 2 and 3 and, again, indicates a possibly strong contribution from a stratospheric intrusion over the northern Pacific. In addition, some Asian air pollution was admixed to the air stream. It is interesting to note that the backward simulations show significant contributions from several source regions in the entire US not identified by the 10-d backward trajectories studied by Trickl et al. (2003),

15 in particular California, which demonstrates the better coverage of remote areas by the retroplume results.

As for Case 1 we recently also performed twenty-day simulations for all the times of the examples in Fig. $6 a$ to $d$ in order to obtain a better estimate of the role of the Asian emissions based on the potentially better overlap with the countries in the Far East.

20 The new tools, again, yield, additional information on the approximate vertical position of the backward plume and the different source contributions.

In Fig. 8 we give an overview of the situation for the altitude range around the highest ozone peak revealed by the lidar and sonde measurements in Fig. 6a (26 May). The column sensitivity plot verifies the rather straight, spatially confined advection from

25 North America already known from our earlier trajectory analysis. This remarkably narrow main portion of the retroplume does not widen much before reaching the Pacific Ocean. Most importantly, the twenty-day retroplume analysis verifies significant stratospheric influence exceeding that in Case 1. The highest altitude on the third panel (about $8.5 \mathrm{~km}$ ) is reached over the central part of Siberia at about $60^{\circ} \mathrm{N}$, as short as

High-ozone layers in the middle and upper troposphere

T. Trickl et al.

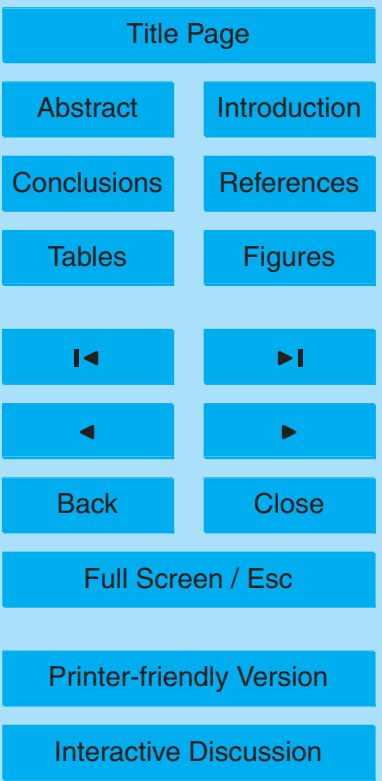

Interactive Discussion 
eleven days backward in time.

A particularly high stratospheric fraction (up to $23 \%$ ) is also calculated for the altitude range above the lidar system between 6.75 and $8.5 \mathrm{~km}$ a.s.l. (not shown). However, we do not possess upper-tropospheric ozone data around this time to judge the impact

5 of this air mass. The early-morning sonde ascent at Hohenpeißenberg ( $38 \mathrm{~km}$ to the north of the lidar) on 26 May shows an ozone rise to $87 \mathrm{ppb}$ above $8 \mathrm{~km}$.

All modelled PBL contributions are at most moderate, less than expected in our earlier study (Trickl et al., 2003). The relative importance of the emissions of the different continents is summarized in Fig. 9. The two principal layers with potential PBL contact 10 observed in the measurements ( 4.6 to $6.5 \mathrm{~km}$ and 7.3 to $12 \mathrm{~km}$ ) are clearly seen in the simulated distributions. The Asian influence in the lower of these layers is higher than in the upper one.

For 27 May, the retroplume analysis (three examples of mean vertical plume positions for the case in Fig. 6c are shown in Fig. 10; those for Fig. 6b look similar) indi15 cates significant stratospheric influence for altitudes above $6 \mathrm{~km}$. As in the May-1996 case a rather shallow transfer is indicated. In contrast to the simulations presented in Fig. 7 some pick-up of stratospheric air over Canada and the north-western Atlantic was found (not shown).

From the "footprints" of the simulations (not shown) it is obvious that PBL contact with East Asia is mostly confined to air masses arriving over Garmisch-Partenkirchen in the range between $7.25 \mathrm{~km}$ and $8 \mathrm{~km}$, i.e., in the altitude range of the big aerosol peak in Figs. $6 \mathrm{~b}$ and $6 \mathrm{c}$. This is confirmed by the vertical distribution of the emissions transported to Garmisch-Partenkirchen (Fig. 11). Also some overlap of the backward plume with the desert regions is found. The aerosol images from the Total Ozone

25 Mapping Spectrometer (TOMS, http://toms.gsfc.nasa.gov/aerosols/aerosols.html) reveal pronounced dust outbreaks in the Takla Makan and, in part, the Gobi desert during the entire month of May. It is, thus, likely that at least the big aerosol peak in Fig. 6b and $\mathrm{c}$ between 7 and $8 \mathrm{~km}$ is caused by dust from the Asian deserts.

The retroplume analysis for the example in Fig. 6d (not shown) yields a significant

High-ozone layers in the middle and upper troposphere

T. Trickl et al.

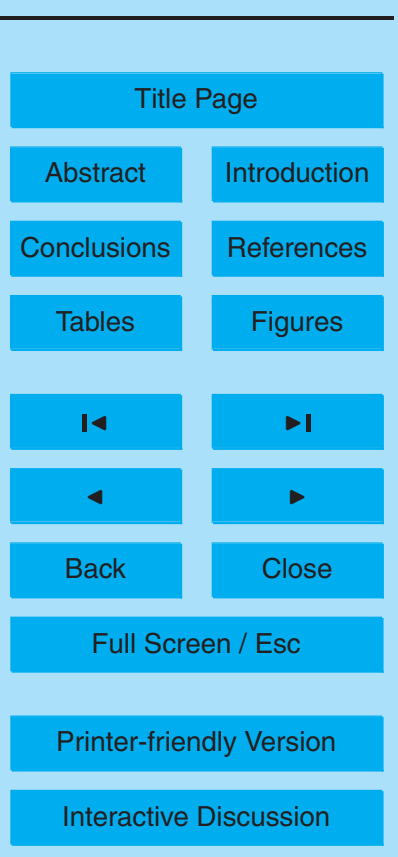


(7-15\%) stratospheric contribution to the air masses in the vertical range between 7.25 and $11 \mathrm{~km}$, for backward times of typically more than fifteen days (less just for the higher altitudes due to the higher wind velocities). Again, a rather shallow transfer is indicated. As to the PBL contributions, there is no relevant Asian influence. Also the import from

5 North America was shown to be rather limited and confined to minor PBL contact to the south east of the US, Cuba and southern California for air masses arriving between 6.25 and $7 \mathrm{~km}$, confirmed by the slightly enhanced aerosol in this altitude range. This suggests that also on 28 May air-mass transfer from the stratosphere is the principal reason for the elevated ozone concentrations at higher altitudes.

10 In summary, we conclude also for the high-ozone layer observed in this case study a highly significant stratospheric component, however, mixed with PBL air during certain periods.

\subsection{Case 3: September 2000}

The lidar measurements between 8 and 11 September 2000, had also not been fully 15 understood at the time of our preceeding paper (Trickl et al., 2003). The results for the first two days are displayed in Fig. 12. The two layers of principal interest are between 4.5 and $6 \mathrm{~km}$ (L2) and between 8 and $10 \mathrm{~km}$ (L1). It had been concluded that L1 on 8 September and early 9 September was mainly caused by ozone import from the south-eastern US, assisted by a number of thunderstorms and possibly influenced by 20 lightning-produced $\mathrm{NO}_{\mathrm{x}}$. The North American influence on $\mathrm{L} 2$ is rather small: $\mathrm{A}$ 10-day FLEXPART retroplume calculation traced most of the $L 2$ air mass back to the tropical Atlantic, ending not far from the African coast. The high ozone values in L2 contrast the low values usually found for an advection from the subtropical Atlantic (Eisele et al., 1999; Carnuth, 2002; Trickl et al., 2003) which are, indeed, seen in the layer below L2.

25 An extended analysis of this air mass and the clean-air import from this area in general will be published separately (Trickl et al., 2009b).

A re-inspection of the trajectory material showed for layer $L 1$ a sudden transition (during the early hours of 9 September) from import from the south-eastern US to a fast,

High-ozone layers in the middle and upper troposphere

T. Trickl et al.

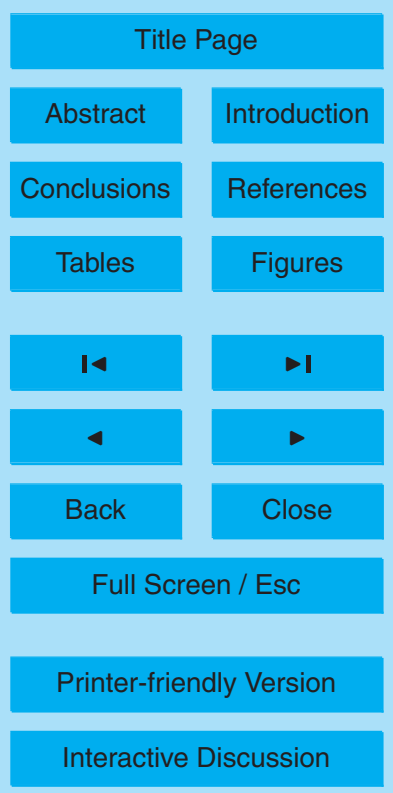


constant-altitude upper-tropospheric air stream from the Pacific Ocean via California. This change was accompanied by an increase in ozone mixing ratio.

In order to analyse the origin of this air stream a twenty-day retroplume analysis was started for 10:00 CET on 9 September. For the altitude range between 7.5 and

$58.5 \mathrm{~km}$ a.s.I. above Garmisch-Partenkirchen, corresponding to layer L1, a clear stratospheric influence is seen, starting about seven days backward in time and rising to about $8 \%$ towards -20 days (see Fig. 13 for FLEXPART results for a $0.25-\mathrm{km}$-layer selected in this range). The stratospheric influence seems to be due to a separate moderate inflow from Canada and a major part of the Arctic region. This inflow is only 10 visible in the column images obtained for 7.5 to $8.5 \mathrm{~km}$. The stratospheric influence between 8.5 and $9.5 \mathrm{~km}$ is less than $5 \%$ and rises above this altitude range, in agreement with the elevated ozone values for that measurement time.

For layer $\mathrm{L} 1$, there is rather little PBL contact, mostly over the subtropical Atlantic from where ozone with very low mixing ratios between 20 and $30 \mathrm{ppb}$ is usually im15 ported. The vertical distribution of emissions (not shown) exhibits rather low values above $4 \mathrm{~km}$, with the exception of a moderate peak of North American emissions between 8 and $9 \mathrm{~km}$, i.e., overlapping with layer L1. A minimum is seen between 4 and $5 \mathrm{~km}$ that corresponds to the subtropical air mass.

The main portion of the air mass above $8.25 \mathrm{~km}$ is traced back to Hawaii, and, for 20 higher start altitudes above the lidar, in a separating branch also to Japan, Korea and China. However, PBL contact is only found over the subtropical Pacific.

\subsection{Case 4: 21 to 24 July 2001}

The lidar measurements between 21 and 24 July (Fig. 14) yielded a particularly nice example of the May-1996 and September-2000 type (Cases 1 and 3), in an analogous 25 way related to a high-pressure zone moving into Central Europe. An ozone layering typical of this kind of weather situation is seen, with stratospheric air (S) descending towards the $\mathrm{PBL}$ in the early phase, low $-\mathrm{O}_{3}$ air from the subtropics above this layer (SA) and air from beyond the Atlantic above $4 \mathrm{~km}$.

High-ozone layers in the middle and upper troposphere

T. Trickl et al.

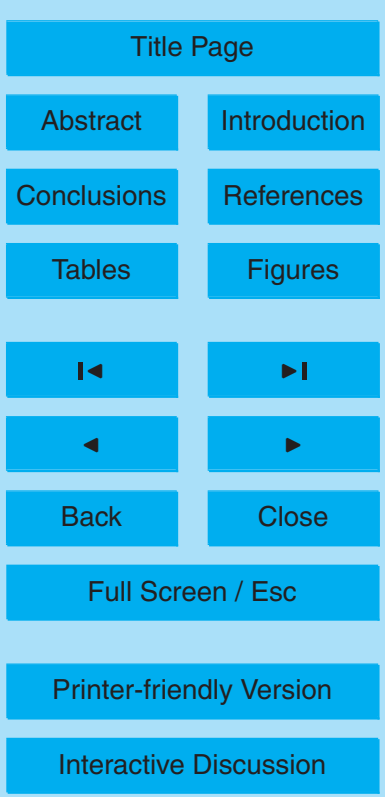


The temporal development above $4 \mathrm{~km}$ starts with the arrival of PBL contributions from the US. The principal source region was first the north-eastern part of the US, later there was also input from other regions. Again with a delay of about two days there was a conspicuous ozone increase between 6 and $8 \mathrm{~km}$, here to values of about $5120 \mathrm{ppb}$. The correctness of the measurements was verified by a comparison with the Hohenpeißenberg ozone sonde on 23 July 2001, launched at 05:41 CET (difference at the ozone peak at $7.5 \mathrm{~km}:+7 \mathrm{ppb}$ for the lidar). From the ozone structure we distinguish several layers. The analysis focusses on the three layers labelled as L1 to L3 in Fig. 14.

Because of the spatial confinement of the most relevant air masses a particu10 larly clear picture of the three-dimensional transport path from $140^{\circ} \mathrm{W}$ to GarmischPartenkirchen is obtained from ten-day FLEXTRA trajectory plots. Two examples for the period of the layers L1 to L3 are shown in Figs. 15 and 16. An onset of air-mass import from the Pacific is observed in the afternoon of 22 July, for altitudes above the lidar between 6 and $8 \mathrm{~km}$ a.s.I. The advection pathway covers parts of Canada and the northern US (see Figs. 15 and 16). For the 01:00-CET calculation (Fig. 15) the upper-tropospheric trajectories (layer L2) mostly correspond to air masses ascending from the PBL over North America and the western part of the Atlantic. The trajectories for layer L1 stay in the upper troposphere and even slightly ascend backward in time as they approach the Pacific. The situation changes in the afternoon of 23 July, when 20 most trajectories above $5 \mathrm{~km}$ stay at high altitudes and end over the Pacific (Fig. 16). There is some indication of separate trajectory bundles for layers L1 and L3.

Since low humidity had been found in the analogous cases we analysed the MOZAIC data for Frankfurt and radiosonde data from the surrounding stations Payerne, Stuttgart and Munich (not shown). The situation is rather complicated due to the strongly is the most adequate station due to westerly advection and, indeed, shows relative humidities of $20 \%$ and less between 5 and $7.5 \mathrm{~km}$. For the higher altitudes Stuttgart (north west) is the better choice during the early phase due to north-westerly advection, with relative humidities between 10 and $20 \%$ in the entire troposphere above $5.6 \mathrm{~km}$.

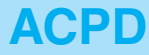

9, 3113-3166, 2009

High-ozone layers in the middle and upper troposphere

T. Trickl et al.

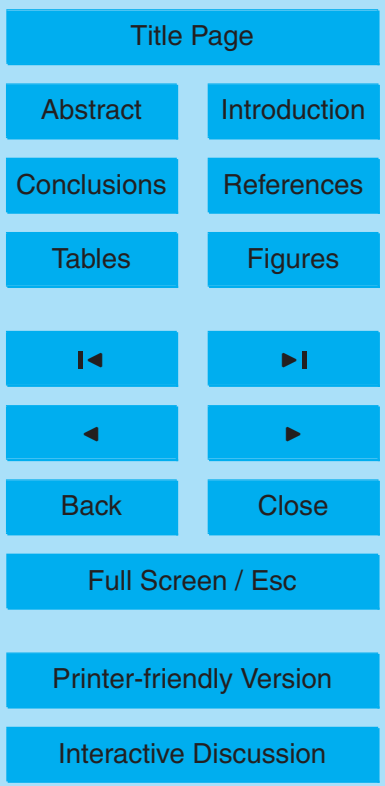

Interactive Discussion 
However, also close to the L3 period relative humidities of down to $11 \%$ are seen above $8 \mathrm{~km}$, presumably because of an advection parallel to that above GarmischPartenkirchen.

Fifteen-day backward simulations with FLEXPART were carried out for all the three 5 layers. We only show the results for layer L3 (Fig. 17). The simulations for the other two layers look similar, but without a clear contact with the East Asian PBL within fifteen days. In addition, for $L 1$ a pronounced intersection of the particle plume with $12 \mathrm{~km}$ is seen over the Atlantic between $157^{\circ}$ and $45^{\circ} \mathrm{N}$ that is missing in the case of L2 and L3.

The results in Fig. 17 for $12 \mathrm{~km}$ altitude, again, indicate significant STT over the 10 Pacific. As in the first two cases, intersections with this level are seen all the way back between the Pacific and the East Atlantic (more than once around the globe). PBL contributions from both North America and East Asia are seen.

For three times on 23 July corresponding to L1-L3, 04:00CET, 07:00 CET and 22:00 CET, twenty-day simulations were contributed, which yielded both a better es15 timate of the potential Asian influence and information on the approximate vertical position of the plume. We discuss here just the results for the first and the last of these three times. The 04:00-CET simulation (not shown) reveals elevated emissions arriving above Garmisch-Partenkirchen between $7 \mathrm{~km}$ and $12 \mathrm{~km}$ with two peaks at about $9 \mathrm{~km}$ and just below $11 \mathrm{~km}$. In agreement with the fifteen-day simulation this ascending air mass is dominated by North American emissions, but the vertical distribution of advected emissions does not explain why there is so much more ozone in layer L1 than in layer L2. However, in L1 an elevated single-day stratospheric influence of up to $12 \%$ is seen. The stratospheric contribution diminishes above L1. Up to $11 \mathrm{~km}$ there is very little stratospheric air mixed into the air stream within the preceding twenty days.

25 In the case of layer L3, where the highest ozone concentration is found, the stratospheric contribution clearly dominates. Figure 18 shows a vertical distribution of the maximum single-day stratospheric fractions for the backward time intervals five to ten and ten to twenty days as extracted from the retroplume analysis. These time intervals cover most of the relevant stratospheric input. The rather pronounced stratospheric

High-ozone layers in the middle and upper troposphere

T. Trickl et al.

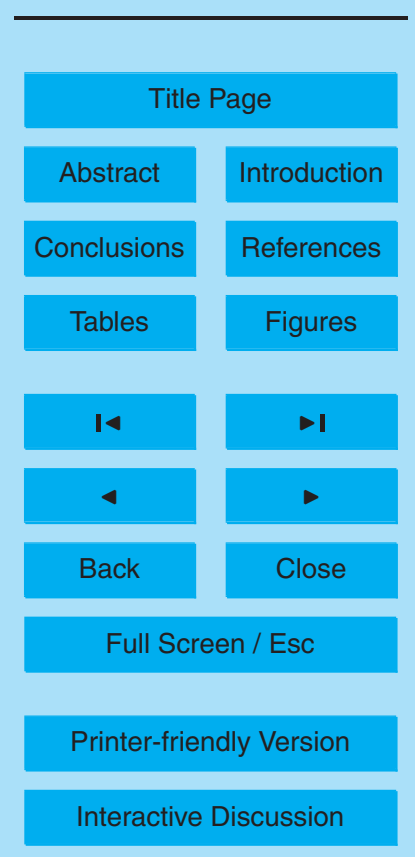


peaks correlate well with the observed ozone maxima for 22:00 CET on 23 July. The stratospheric fraction for layer $L 3(9 \mathrm{~km})$ is particularly high. Given this high fraction, the observed peak ozone mixing ratios of about $120 \mathrm{ppb}$ look somewhat low remembering the findings for the other cases for which lower stratospheric fractions were found. Also

5 a high-resolution hemispheric Eulerian simulation by our project partner EURAD (not shown; for details on the model see ATMOFAST, 2005; Trickl et al., 2009a) significantly overestimates the ozone mixing ratios in this layer.

The time-altitude plot for layer L3 (not shown) shows four partial clusters of the plume, the upper three always staying above $6 \mathrm{~km}$ and the uppermost one never get10 ting below $10 \mathrm{~km}$. This confirms the tendency seen in the trajectory plot (Fig. 16) and, again, suggests rather shallow STT.

The vertical distribution of emissions for layer L3 (not shown) show only half the mixing ratios calculated for $L 1$ and $L 2$. But they include a much higher Asian fraction, as already indicated in the fifteen-day simulations. A moderate North American spike at $8 \mathrm{~km}$ is likely to be an extension of layer L1.

\subsection{Case 5: August 2001}

The ozone observations between 12 and 15 August 2001, shown in Fig. 19, yielded particularly spectacular (long-lasting) upper-tropospheric high-ozone layers. This case is also less complex than those so far discussed, with an almost exclusive stratospheric 20 source of the elevated ozone, which underlines the importance of STT for this type of layers.

Although not that clearly visible, this case yields another example for the "classical" pattern seen after the onset of high-pressure periods as in the cases shown in Figs. 12 and 14. The characteristic stratospheric intrusion (S) was observed during the first 25 half of 12 August (see Trickl et al., 2009a, for more details). What is special is the rather short presence of the subtropical air stream (SA) as well as an ozone peak at $4 \mathrm{~km}$ not associated with the intrusion, but with long-range advection (LA) from high altitudes above the northern Pacific. The Zugspitze ${ }^{7}$ Be value on 13 August was above

High-ozone layers in the middle and upper troposphere

T. Trickl et al.

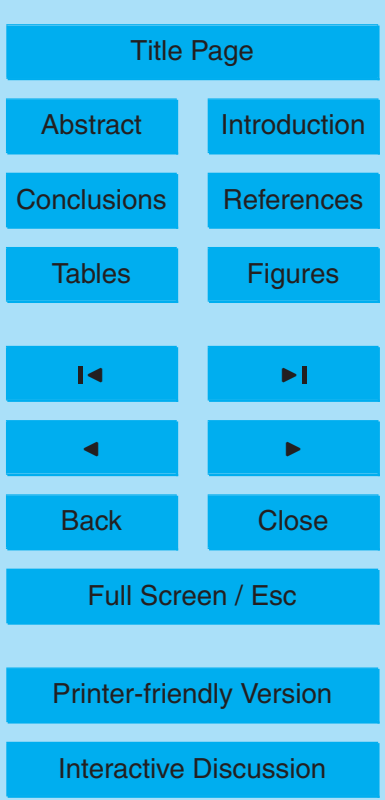


$8 \mathrm{mBq} \mathrm{m}^{-3}$ which strongly suggests stratospheric influence.

Above $5 \mathrm{~km}$ a pronounced rise in ozone is seen starting on 13 August. As in the May1999 case this layer persisted for several days, the measurements were stopped in the evening of 15 August for technical reasons. The peak ozone mixing ratios, observed 5 between 8 and $10 \mathrm{~km}$, exceeded $120 \mathrm{ppb}$ (up to $140 \mathrm{ppb}$ on 14 August), confirmed by the sonde ascent at Hohenpeißenberg on 15 August. The data of the Munich radiosonde show very dry conditions within the high-ozone layer with the exception of 13 August, 12:00 UTC. On 14 August relative humidities down to $7 \%$ are listed for the altitude range between 7.9 and $9.8 \mathrm{~km}$.

10 FLEXPART twenty-day retroplume calculations were carried out for three different times during the observational period. Figure 20 shows as an example the retroplume analysis for the simulation corresponding to the most pronounced ozone feature (14 August, 03:00 CET). The most likely source of the elevated ozone is input from the stratosphere over the western US and over the Pacific. There is little PBL influence.

15 This layer is confirmed by an EURAD simulation (Fig. 7 in Trickl, 2009a). However, the calculated ozone values do not exceed $80 \mathrm{ppb}$. The EURAD CO values are 50 to $60 \mathrm{ppb}$ indicating the absence of air pollution.

\section{Discussion and conclusions}

The backward analyses presented in this paper have added some significant information on mid- and upper-tropospheric dry high-ozone layers rather consistently observed with the lidar one or two days after the beginning of high-pressure periods (see Trickl et al., 2009a, for another example). The model-based analysis demonstrates pronounced stratospheric contributions mostly entering the tropophere over the Pacific and Asia. In some of the cases simultaneous air pollution import from East Asia, North America was found. The layers vary considerably in thickness and length from case to case.

In several cases the stratospheric influence clearly dominated these layers. The transfer from the stratosphere into the, in part, rapidly traveling air streams is very

High-ozone layers in the middle and upper troposphere

T. Trickl et al.

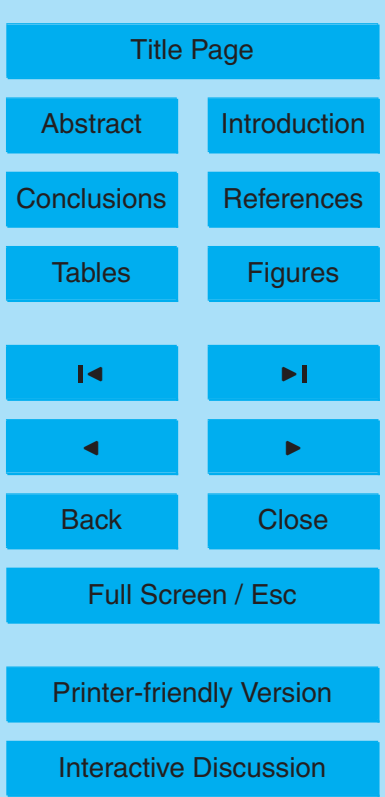


likely rather shallow on average. Some of these air masses travel around the globe at mid-latitudes within just fifteen days. The ozone-rich air streams were rather coherent and could be mostly followed from Europe backward to the eastern Pacific even by trajectories. However, there is a clear gain in information for the long traveling times by 5 using the FLEXPART analysis tools.

The fact that the stratospheric component was almost exclusive in some of the cases demonstrates that these air streams may be associated with a possibly very important mechanism of STT. The layers, containing 100 to $150 \mathrm{ppb}$ of ozone, are several kilometres thick, may extend over several days and do not exhibit the significant drop in ozone 10 concentration after a rather short period with enhanced ozone as seen in the case of the direct intrusions most commonly observed at the Zugspitze summit. The humidity in these layers is low, but not negligible, despite their considerable width, which indicates a contribution of tropospheric air. This is obvious for the cases with aerosol observations.

15 The existence of aerosol in some of the layers suggests contributions from a remote PBL. In the most spectacular case (May 1999) the FLEXPART analysis suggests the presence of dust from the Takla Makan and Gobi deserts. However, it is difficult to quantify the impact of East Asian emissions. There are large uncertainties in the emission inventories (Ma and van Aardenne, 2004). This uncertainty is enhanced due to the strong positive trend in emissions in that region, with more than a doubling of the $\mathrm{NO}_{2}$ peak values from 1995 to 2004 (Richter et al., 2005; see also: Ding et al., 2008). It would be helpful to obtain more observations with dominating East Asian influence. However, such cases are obviously difficult to find and we know of just a single, very recent study of an Asian plume reaching Europe after transport across the North Pacific, North America and the North Atlantic (Stohl et al., 2007). The analysis of our measurements shows that most of these air streams contain some fraction of North American air pollution. However, a few aerosol observations in the free troposphere in our long-term series (Jäger, 2005) could be traced back to the Pacific area using FLEXTRA results (ATMOFAST, 2005; Jäger et al., 2006) and will be analysed further.

High-ozone layers in the middle and upper troposphere

T. Trickl et al.

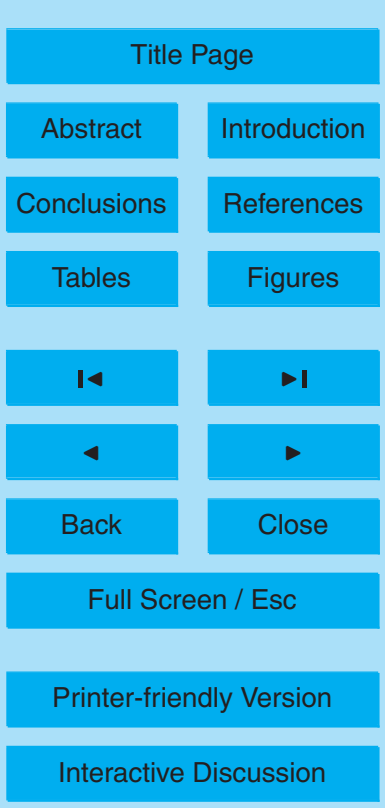

Interactive Discussion 
We found by trajectory analyses for several years of free-tropospheric lidar measurements that aerosol is a suitable indicator of PBL air, although its free tropospheric abundance is mostly low (ATMOFAST, 2005; Jäger et al., 2006). This is perhaps due to washout in the WCBs during convectively lifting the PBL air to the free troposphere, 5 or due to dilution in diverging air masses. In our free-tropospheric soundings available since 1992 the aerosol backscatter coefficients above $3 \mathrm{~km}$ or the PBL have rarely exceeded the Rayleigh background at $532 \mathrm{~nm}$ (which corresponds to a visual range of $300 \mathrm{~km}$ at sea level) by more than $50 \%$, even during strong fire years in the US. Due to the high sensitivity of our NDACC lidar system (free-tropospheric threshold 10 for aerosols: about $2 \%$ of the Rayleigh background) these structures are, nevertheless, clearly visible. Really strong aerosol signatures have only be detected above Garmisch-Partenkirchen during Saharan dust outbreaks, that reach up to $6 \mathrm{~km}$ (Jäger et al., 1988; Kreipl et al., 2001; Papayannis et al., 2008), and in Canadian fire plumes, e.g., in August 1998 (Forster et al., 2001) and in July 2004 (during the ICARTT (Fehsenfeld et al., 2006) campaign (ATMOFAST, 2005)).

The model results also reveal that there may be problems in quantitatively predicting the amount of ozone imported from the stratosphere into these rapid air streams. One possible reason could be the pronounced spatial and seasonal variation of ozone in the lowermost stratosphere ranging between 100 and $500 \mathrm{ppb}$ (Thouret et al., 2006). This

is confirmed by our lidar measurements that occasionally show strong concentration changes above the tropopause on a time scale of one to two hours.

The analysis may be further complicated by lightning. In all cases discussed in the 2003 paper, which are also part of the present study, thunderstorms or large convective cells have been detected in the areas where PBL air is lifted to the middle troposphere.

25 Huntrieser et al. (2007) conclude from measurements over South America that the outflow from mesoscale convective systems may yield significantly enhanced ozone mixing ratios (roughly from $35-40 \mathrm{ppb}$ to $60-80 \mathrm{ppb}$ in the case described) at distances of several hundred kilometres away from the source. A number of recent publications verify a significant ozone contribution from lightning-generated $\mathrm{NO}_{\mathrm{x}}$ for the US and

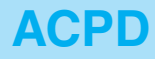

9, 3113-3166, 2009

High-ozone layers in the middle and upper troposphere

T. Trickl et al.

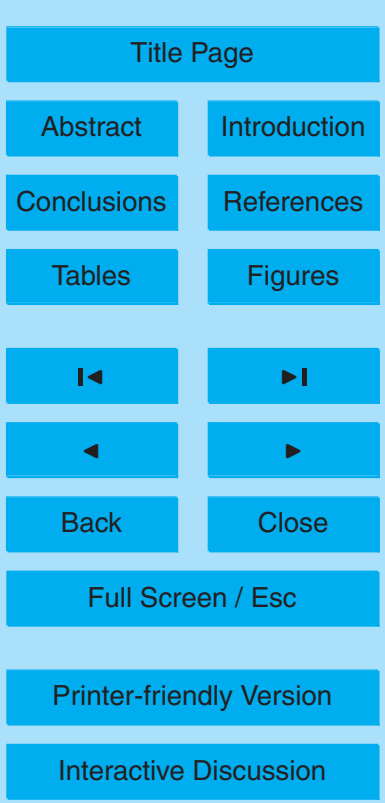


adjacents marine regions (Beirle et al., 2006; Cooper et al., 2006; Liang et al., 2007; Schumann and Huntrieser, 2007; Singh et al., 2007; Sioris et al., 2007). Cooper et al. (2006) conclude from the large data set collected during the ICARTT campaign that most of the ozone enhancement over the eastern US (excluding stratospheric 5 contributions) in July and August 2004 was due to lightning-generated $\mathrm{NO}_{\mathrm{x}}$.

In many cases mixing of different contributions within or in the vicinity of frontal systems over the Pacific takes place. The proximity of the most important WCB inflow region to East Asia is an important factor (Stohl, 2001, and references therein). The WCB lifts the Asian air masses towards the North Pacific where many of the air flows 10 observed above our site pass by. We have started to speculate on a potential impact of the rising Asian air pollution on the ozone concentrations in the upper troposphere and the lower stratosphere (UTLS). Indeed, an analysis of MOZAIC data between 1994 and 2003 has revealed a positive ozone trend in the UTLS (Thouret al al., 2006). This is confirmed by the analysis of the Hohenpeißenberg sounding record from 1966 to 152007 (Claude et al., 2008), showing a +7.5-\%/decade trend after 1994 that is limited to a narrow range around $14 \mathrm{~km}$. A preliminary analysis of the Zugspitze CO within ATMOFAST has yielded a slightly positive trend of $\mathrm{CO}$ in stratospheric intrusions since the beginning of the CO measurements in 1990, opposing the slightly negative trend for non-stratospheric conditions (ATMOFAST, 2005).

20 More measurements are needed to harden further the reproducibility of these observations. In particular, we plan to intensify simultaneous lidar sounding of ozone, water vapour and aerosols. Accurate side-by-side $\mathrm{H}_{2} \mathrm{O}$ measurements are needed as an important information for quantifying the tropospheric influence in these dry air streams. Our new high-power water-vapour lidar has yielded humidity profiles for the entire troposphere with just minor restrictions during daytime, as a result of an application of the differential-absorption technique (Vogelmann and Trickl, 2008).

Acknowledgements. The authors thank P. Fabian and W. Seiler for their continual interest and support. They are indebted to P. James who carried out the 15-day simulations with FLEXPART, but cannot co-author this paper for specific reasons. They thank H. Feldmann for gen-

High-ozone layers in the middle and upper troposphere

T. Trickl et al.

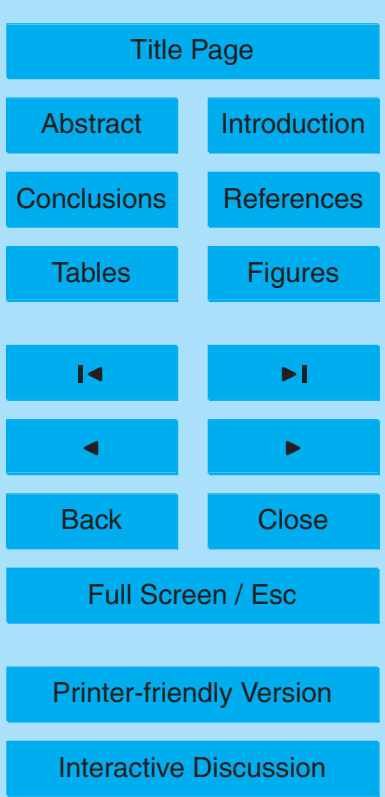


erating plots from the one-year EURAD run for 2001, J. Keller for preparing the PSI sonde system and carefully archiving the data, $\mathrm{H}$. E. Scheel for providing the local station data, and $\mathrm{H}$. Jäger for making available his aerosol data. Furthermore, they thank the MOZAIC team for allowing them to access their data base, A. Volz-Thomas for his help with some of the

5 MOZAIC publications, as well as R. Steinbrecher and L. G. Ruiz Suárez for providing the link to the web site on the station data for Mexico City. H. Claude made available data from the Hohenpeißenberg sonde archive. This work has been funded by the European Union within the VOTALP (Vertical Ozone Transport in the Alps, parts 1 and 2), STACCATO (Influence of Stratosphere-Troposphere Exchange in a Changing Climate on Atmospheric Transport and 10 Oxidation Capacity) and EARLINET (European Aerosol Research Lidar Network) projects as well as by the German Bundesministerium für Bildung und Forschung within the programme "Atmosphärenforschung 2000" (ATMOFAST project: Atmospheric Long-range Transport and its Impact on the Trace-gas Composition in the Free Troposphere over Central Europe) and the German Aerosol Lidar Network.

\section{References}

AFO 2000: Results of the German Atmospheric Research Programme, edited by: Winkler, R., German Federal Ministry of Education and Research (BMBF), Publications and Website Division, Berlin, Germany, 265 pp., 2005.

ATMOFAST: Atmosphärischer Ferntransport und seine Auswirkungen auf die Spurengaskonzentrationen in der freien Troposphäre über Mitteleuropa (Atmospheric Long-range Transport and its Impact on the Trace-gas Composition of the Free Troposphere over Central Europe), Project Final Report, T. Trickl, Co-ordinator, M. Kerschgens, A. Stohl, and T. Trickl, subproject co-ordinators, funded by the German Ministry of Education and Research within the programme "Atmosphärenforschung 2000", 130 pp., 2005 (in German).

25 Austin, J. F. and Midgley, R. P.: The Climatology of the jet stream and stratospheric intrusions of ozone over Japan, Atmos. Environ., 28, 39-52, 1994.

Beirle, S., Spichtinger, N., Stohl, A., Cummins, K. L., Turner, T., Boccippio, D., Cooper, O. R., Wenig, M., Grzegorski, M., Platt, U., and Wagner, T.: Estimating the $\mathrm{NO}_{x}$ produced by lightning from GOME and NLDN data: a case study in the Gulf of Mexico, Atmos. Chem. Phys., 6, 1075-1089, 2006, http://www.atmos-chem-phys.net/6/1075/2006/.

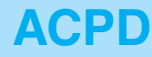

9, 3113-3166, 2009

High-ozone layers in the middle and upper troposphere

T. Trickl et al.

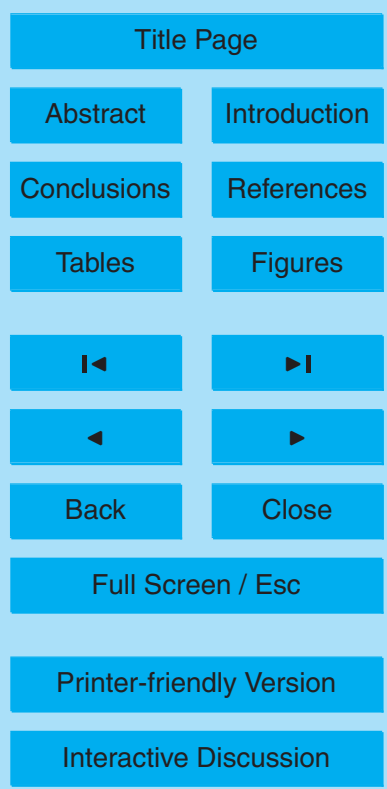


Bithell, M., Vaughan, G., and Gray, L. J.: Persistence of stratospheric ozone layers in the troposphere, Atmos. Environ., 34, 2563-2570, 2000.

Carnuth, W., Kempfer, U., and Trickl, T.: Highlights of the Tropospheric Lidar Studies at IFU within the TOR Project, Tellus B, 54, 163-185, 2002.

5 Claude, H., Steinbrecht, W., and Köhler, U.: Entwarnung bei der Ozonschicht, Ozonbulletin des Deutschen Wetterdiensts; available from http://www.dwd.de, 119, 2, 2008 (in German).

Cooper, O. R., Forster, C., Parrish, D., Trainer, M., Dunlea, E., Ryerson, T., Hübler, G., Fehsenfeld, F., Nicks, D., Holloway, J., de Gouw, J., Warneke, C., Roberts, J. M., Flocke, F., and Moody, J.: A case study of transpacific warm conveyor belt transport: Infuence of merging airstreams on trace gas import to North America, J. Geophys. Res., 109, D23S08, doi:10.1029/2003JD003624, 2004a.

Cooper, O., Forster, C., Parrish, D., Dunlea, E., Hübler, G., Fehsenfeld, F., Holloway, J., Oltmans, S., Johnson, B., Wimmers, A., and Horowitz, L.: On the life cycle of a stratospheric intrusion and its dispersion into polluted warm conveyor belts, J. Geophys. Res., 109, D23S09, doi:10.1029/2003JD00400618, 2004b.

Cooper, O. R., Stohl, A., Hübler, G., Hsie, E. Y., Parrish, D. D., Tuck, A. F., Kiladis, G. N:, Oltmans, S. J., Johnson, B. J., Shapiro, M., Moody, J. L, and Lefohn, A. S.: Direct transport of midlatitude stratospheric ozone into the lower troposphere and marine boundary layer of the tropical Pacific Ocean, J. Geophys. Res., 100, D23310, doi:10.1029/2005JD005783, 2005.

Cooper, O. R., Stohl, A., Trainer, M., Thompson, A. M., Witte, J. C., Oltmans, S. J., Morris, G., Pickering, K. E., Crawford, J. H., Chen, G., Cohen, R. C., Bertram, T. H., Wooldridge., P., Perring, A., Brune, W. H., Merrill, J., Moody, J. L., Tarasick, D., Nédélec, P., Forbes, G., Newchurch, M. J., Schmidlin, F. J., Johnson, B. J., Turquety, S., Baughcum, S. L., Ren, X., Fehsenfeld, F. C., Meagher, J. F., Spichtinger, N., Brown, C. C., McKeen, S. A., McDermid, I. S., and Leblanc, T.: Large upper tropospheric ozone enhancements above midlatitude North America during summer: In situ evidence from the IONS and MOZAIC ozone measurements network, J. Geophys. Res. 111, D24S05, doi:10.1029/2006JD007306, 2006.

Cristofanelli, P., Bonasoni, P., Collins, W., Feichter, J., Forster, C., Kentarchos, A., Kubik, P. W., James, P., Land, C., Meloen, J., Roelofs, G. J., Siegmund, P., Sprenger, M., Schnabel, C., Stohl, A., Tositti, L., Trickl, T., Wernli, H., and Zanis, P.: Stratosphere to troposphere transport: a model and method evaluation, J. Geophys. Res., 108, 8525, doi:10.1029/2002JD002600, 2003. 
Davis, T. D. and Schuepbach, E.: Episodes of high ozone concentrations at the earth's surface resulting from transport down from the upper troposphere/lower stratosphere: a review and case studies, Atmos. Environ., 28, 53-68, 1994.

Deshler, T., Anderson-Sprecher, R., Jäger, H., Barnes, J., Hofmann, D. J., Clemensha, B., Simonich, D., Grainger, R. G., and Godin-Beekmann, S.: Trends in the non-volcanic component of stratospheric aerosol over the period 1971-2004, J. Geophys. Res., 111, D01201, doi:10.1029/2005JD00608, 2006.

Ding, A. J., Wang, T., Thouret, V., Cammas, J.-P., and Nédélec, P.: Tropospheric ozone climatology over Beijing: analysis of aircraft data from the MOZAIC program, Atmos. Chem.

10 Phys., 8, 1-13, 2008, http://www.atmos-chem-phys.net/8/1/2008/.

Eisele, H. and Trickl, T.: Second Generation of the IFU Stationary Tropospheric Ozone Lidar, in: Advances in Atmospheric Remote Sensing with Lidar, Selected Papers of the 18th International Laser Radar Conference, Berlin (Germany), July 22 to 26, 1996, edited by: Ansmann, A., Neuber, R., Rairoux, P., Wandinger, U., Springer, Berlin, Heidelberg, Germany, pp. 379-382, 1997.

Eisele, H. and Trickl, T.: Improvements of the aerosol algorithm in ozone-lidar data processing by use of evolutionary strategies, Appl. Optics, 44, 2638-2651, 2005.

Eisele, H., Scheel, H. E., Sladkovic, R., and Trickl, T.: High-resolution Lidar Measurements of Stratosphere-troposphere Exchange, J. Atmos. Sci., 56, 319-330, 1999.

Elbern, H., Kowol, J., Sladkovic, R., and Ebel, A.: Deep stratospheric intrusions: A statistical assessment with model guided analysis, Atmos. Environ., 31, 3207-3226, 1997.

Fehsenfeld, F. C., Ancellet, G., Bates, T. S., Goldstein, A. H., Hardesty, R. M., Honrath, R., Law, K. S., Lewis, A. C., Leaitch, R., McKeen, S., Meagher, J., Parrish, D. D., Pszenny, A. A. P., Russell, P. B., Schlager, H., Seinfeld, J., Talbot, R., and Zbinden, R.: International consortium for atmospheric research on transport and transformation (ICARTT): North America to Europe - Overview of the 2004 summer field study, J. Geophys. Res., 111, D23S01, doi:10.1029/2006JD007829, 2006.

Feldmann, H., Memmesheimer, M., Ebel, A., Seibert, P., Wotawa, G., Kromp-Kolb, H., Trickl, T., and Prévôt, A.: Evaluation of a Regional Scale Model for the Alpine Region with Data from the VOTALP Project, in: Proceedings of EUROTRAC Symposium 1998, GarmischPartenkirchen (Germany), March 23-17, 1998, edited by: Borrell, P. M. and Borrell, P., WITpress, Southampton (Great Britain), pp. 483-488, 1999.

Forster, C., Wandinger, U., Wotawa, G., James, P., Mattis, I., Althausen, D., Simmonds, P.,

\section{High-ozone layers in the middle and upper troposphere}

T. Trickl et al.

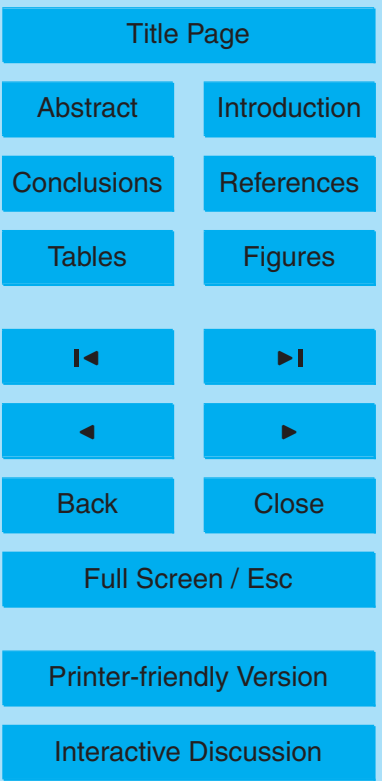


O'Doherty, S., Jennings, S. G., Kleefeld, C., Schneider, J., Trickl, T., Kreipl, S., Jäger, H., and Stohl, A.: Transport of boreal forest fire emissions from Canada to Europe, J. Geophys. Res., 106, 22887-22906, 2001.

Freudenthaler, V., Homburg, F., and Jäger, H.: Ground-based mobile scanning LIDAR for remote sensing of contrails, Ann. Geophys., 12, 956-961, 1994,

http://www.ann-geophys.net/12/956/1994/.

Fromm, M., Shettle, E. P., Fricke, K. H., Ritter, C., Trickl, T., Giehl, H., Gerding, M., Barnes, J., O'Neill, M., Massie, S. T., Blum, U., McDermid, I. S., Leblanc, T., and Deshler, T.: The stratospheric impact of the Chisholm PyroCumulonimbus eruption: 2. Vertical profile perspective, J. Geophys. Res., 113, D08203, doi:10.1029/2007JD009147, 2008.

Frost, G. J., McKeen, S. A., Trainer, M., Ryerson, T. B., Neuman, J. A., Roberts, J. M., Swanson, A., Holloway, J. S., Sueper, D. T., Parrish, D. D., Fehsenfeld, F. C., Flocke, F., Peckham, S. E., Grell, G. A., Kowal, D., Cartwright, J., Auerbach, N., and Habermann, T.: Effects of changing power plant $\mathrm{NO}_{\mathrm{x}}$ emissions on ozone in the eastern United States: Proof of concept, J. Geophys Res., 111, D12306, doi:10.1029/2005JD006354, 2006.

Huntrieser, H., Heland, J., Schlager, H., Forster, C., Stohl, A., Aufmhoff, H., Arnold, F., Scheel, H. E., Campana, M., Gilge, S., Eixmann, R., and Cooper, O.: Intercontinental air pollution transport from North America to Europe: Experimental evidence from aircraft measurements and surface observations, J. Geophys. Res., 110, DO1305, doi:10.1029/2004JD005045, 2005.

Huntrieser, H., Schlager, H., Roiger, A., Lichtenstern, M., Schumann, U., Kurz, C., Brunner, D., Schwierz, C., Richter, A., and Stohl, A.: Lightning-produced $\mathrm{NO}_{x}$ over Brazil during TROCCINOX: airborne measurements in tropical and subtropical thunderstorms and the importance of mesoscale convective systems, Atmos. Chem. Phys., 7, 2987-3013, 2007, http://www.atmos-chem-phys.net/7/2987/2007/.

Jäger, H.: Long-term record of lidar observations of the stratospheric aerosol layer at GarmischPartenkirchen, J. Geophys. Res., 110, D08106, doi:10.1029/2004JD005506, 2005.

Jäger, H., Carnuth, W., and Georgi, B.: Observations of Saharan Dust at a North Alpine Station, J. Aerosol Sci., 19, 1235-1238, 1988

30 Jäger, H., Kreipl, S., James, P., Stohl, A., and Trickl, T.: Long-range Transport and its Impact on the Vertical Distribution of Trace Constitutents in the Central European Free Troposphere, in: Reviewed and Revised Papers Presented at the 22nd International Laser Radar Conference, Matera, Italy, July 12 to 16, 2004, edited by: Pappalardo, G., Amodeo, A., and Warmbein, B.,

\section{ACPD}

9, 3113-3166, 2009

High-ozone layers in the middle and upper troposphere

T. Trickl et al.

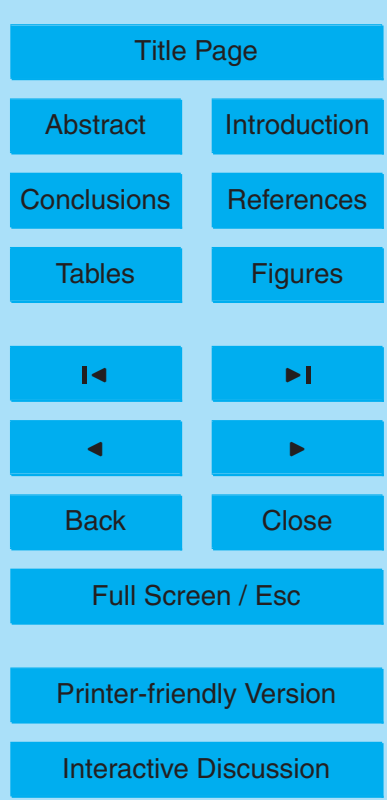


ESA Publications Division, Noordwijk, The Netherlands, pp. 679-682, 2004, ISBN 92-9092872-7, ISSN 0379-6566.

Jäger, H., James, P., Stohl, A., and Trickl, T: Long-Range Transport of Free-Tropospheric Aerosol: A Nine-year Climatology, in: Reviewed and Revised Papers Presented at the 23rd International Laser Radar Conference, Nara (Japan), July 24 to 28, 2006, edited by: Nagasawa, C., Sugimoto, N., Tokyo Metropolitan University, Tokyo, Japan, pp. 795-796, 2006, ISBN 4-9902916-0-3.

James, P., Stohl, A., Forster, C., Eckhardt, S, Seibert, P., and Frank, A.: A 15-year climatology of stratosphere-troposphere exchange with a Lagrangian particle dispersion model, 2. Mean climate and seasonal variability, J. Geophys. Res., 108, 8522, doi:10.1029/2002JD002639, 2003.

Kanter, H.-J., Scheel, H. E., Trickl, T., James, P., Stohl, A., and Feldmann, H.: Atmospheric Long-range Transport and its Impact on the Trace-gas Distribution in the Free Troposphere over Central Europe (ATMOFAST), in: Ozone, Proceedings of the XXth Quadrennial Ozone Symposium, Kos (Greece), 1 to 8 June 2004, edited by: Zerefos, C., University of Athens (Athens, Greece, 2004)/International Ozone Commission, Genève, Switzerland, pp. 849850, 2004, ISBN 960-630-103-6, ISBN 960-630-105-2

Kempfer, U., Carnuth, W., Lotz, R., and Trickl, T.: A wide-range UV lidar system for tropospheric ozone measurements: development and application, Rev. Sci. Instrum., 65, 3145-3164, $20 \quad 1994$

Komhyr, W. D.: Electrochemical concentration cells for gas analysis, Ann. Geophys., 25, 203210, 1969.

Kreipl, S., Mücke, R., Jäger, H., Trickl, T., and Stohl, A.: Spectacular Cases of Vertical and Long-range Ozone and Aerosol Transport, in: Laser Remote Sensing of the Atmosphere, Selected Papers of the 20th International Laser Radar Conference, Vichy (France), July 10 to 14, 2000, edited by: Dabas, A., Pelon, J., Éditions de l'École Polytechnique, Paris, France, pp. 455-458, 2001.

Kritz, M. A., Le Roulley, J.-C., and Danielsen, E. F.: The China Clipper - fast advective transport of radon-rich air from the Asian boundary layer to the upper troposphere near California, 30 Tellus B, 42, 46-61, 1990.

Law, K. S., Penkett, S. A., Reeves, C. E., Evans, M. J., Pyle, J. A., Bauguitte, S., Green, T. J., Bandy, B., Mills, G. P., Barjat, H., Kley, D., Schmitgen, S., Monks, P. S., Edwards, G. D., Kent J. M., Dewey, K., and Kaye, A.: Evidence for anthropogenic influence over the central 
North Atlantic. IGACtivities, International Global Atmospheric Chemistry, Newsletter 24, 1719, 2001.

Liang, Q., Jaeglé, L., Hudman, R. C., Turquety, S., Jacob, D. J., Avery, M. A., Browell, E. V., Sachse, G. W., Blake, D. R., Brune, W., Ren, X., Cohen, R. C., Dibb, J. E., Fried, A., Fuelberg, H., Porter, M., Heikes, B. G., Huey, G., Singh, H. B., and Wennberg, P. O.: Summertime influence of Asian pollution in the free troposphere over North America, J. Geophys. Res., 112, D12S11, doi:10.1029/2006JD007919, 2007.

$\mathrm{Ma}$, J. and van Aardenne, J. A.: Impact of different emission inventories on simulated tropospheric ozone over China: a regional chemical transport model evaluation, Atmos. Chem. Phys., 4, 877-887, 2004, http://www.atmos-chem-phys.net/4/877/2004/.

Marenco, A., Thouret, V., Nédélec, P., Smit, H., Helten, M., Kley, D., Karcher, F., Simon, P., Law, K., Pyle, J., Poschmann, G., von Wrede, R., Hume, C., and Cook, T.: Measurement of ozone and water vapor by Airbus in-service aircraft: The MOZAIC airborne program, An overview, J. Geophys. Res., 103, 25631-25642, 1998.

Meloen, J., Siegmund, P., van Velthoven, P., Kelder, H., Sprenger, M., Wernli, H., Kentarchos, A., Roelofs, G., Feichter, J., Land, C., Forster, C., James, P., Stohl, A., Collins, B., and Cristofanelli, P.: Stratosphere troposphere exchange: a model and method intercomparison, J. Geophys. Res., 108, 8526, doi:10.1029/2002JD002274, 2003.

Newell, R. E., Thouret, V., Cho, J. Y. N., Stoller, P., Marenco, A., and Smit, H. G.: Ubiquity of quasi-horizontal layers in the troposphere, Nature, 198, 316-319, 1999.

Olivier, J. G. J. and Berdowski, J. J. M.: Global emissions sources and sinks, in: The Climate System, edited by: Berdowski, J., Guicherit, R., Heij, B. J., A. A. Balkema Publishers/Swets \& Zeitlinger Publishers, Lisse, The Netherlands, ISBN 905809255 0, pp. 33-78 (2001).

Papayannis, A., Amiridis, V., Mona, L., Tsaknakis, G., Balis, D., Bösenberg, J., Chaikovski, A., 25 De Tomasi, F., Grigorov, I., Mattis, I., Mitev, V., Müller, D., Nickovic, S., Pérez, C., Pietruczuk, A., Pisani, G., Ravetta, F., Rizi, V., Sicard, M., Trickl, T., Wiegner, M., Gerding, M., Mamouri, R. E., D'Amico, G., and Pappalardo, G.: Systematic lidar observations of Saharan dust over Europe in the frame of EARLINET (2000-2002), J. Geophys. Res., 113, D10204; doi:10.1029/2007JD009028, 2008.

so Penkett, S. A., Evans, M. J., Reeves, C. E., Law, K. S., Monks, P. S., Bauguitte, S. J. B., Pyle, J. A., Green, T. J., Bandy, B. J., Mills, G., Cardenas, L. M., Barjat, H., Kley, D., Schmitgen, S., Kent, J. M., Dewey, K., and Methven, J.: Long-range transport of ozone and related pollutants over the North Atlantic in spring and summer, Atmos. Chem. Phys. Discuss., 4, 
4407-4454, 2004, http://www.atmos-chem-phys-discuss.net/4/4407/2004/.

Prados, A. I., Dickerson, R. R., Doddrige, B. G., Milne, P. A., Moody, J. L., and Merrill J. T.: Transport of ozone and pollutants to the North Atlantic Ocean during the 1996 Atmosphere/Ocean Chemistry Experiment (AEROCE) intensive, J. Geophys. Res., 104, 262195 26233, 1999.

Reiter, R., Sladkovic, R., Pötzl, K., Carnuth, W., and Kanter, H.-J.: Studies of the influx of stratospheric air into the lower troposphere using cosmic-ray-produced radionuclides and fallout, Arch. Meteor. Geophy. A, 20A, 211-246, 1971.

Reiter, R., Sladkovic, R., and Kanter, H.-J.: Concentration of trace gases in the lower troposphere, simultaneously recorded at neighboring mountain stations, Part II: ozone, Meteorol. Atmos. Phys., 37, 27-47, 1987.

Richter, A., Burrows, J. P., Nüß, H., Granier, C., and Niemeier, U.: Increase in tropospheric nitrogen dioxide over China oberved from Space, Nature, 437, 129-132, 2005.

Roelofs, G. J., Kentarchos, A. S., Trickl, T., Stohl, A., Collins, W. J., Crowther, R. A., Hauglus15 taine, D., Klonecki, A., Law, K. S., Lawrence, M. G., von Kuhlmann, R., and van Weele, M.: Intercomparison of tropospheric ozone models: Ozone transport in a complex tropopause folding event, J. Geophys. Res., 108, 8529, doi:10.1029/2003JD003462, 2003.

Schuepbach, E., Davies, T. D., Massacand, A. C., and Wernli, H.: Mesoscale modelling of vertical atmospheric transport in the Alps associated with the advection of a tropopause fold - a winter ozone episode, Atmos. Environ., 33, 3613-3626, 1999.

Schumann, $U$. and Huntrieser, $H .:$ The global lightning-induced nitrogen oxides source, Atmos. Chem. Phys., 7, 3823-3907, 2007, http://www.atmos-chem-phys.net/7/3823/2007/.

Seibert, P., Feldmann, H., Neininger, B., Bäumle, M., and Trickl, T.: South foehn and ozone in the Eastern Alps - case study and climatological aspect, Atmos. Environ., 34, 1379-1394, 2000.

Singh, H. B., Salas, L., Herlth, D., Kolyer, R., Czech, E., Avery, M., Crawford, J. H., Pierce, R. B., Sachse, G. W., Blake, D. R., Cohen, R. C., Bertram, T. H., Perring, A., Wooldridge, P. J., Dibb, J., Huey, G., Hudman, R. C., Turquety, S., Emmons, L. K., Flocke, F., Tang, Y., Carmichael, G. R., and Horowitz, L. W.: Reactive nitrogen distribution and partitioning in the North American troposphere and lowermost stratosphere, J. Geophys. Res. 112, D12S04, doi:10.1029/2006JD007664, 2007.

Sioris, C. E., McLinden, C. A., Martin, R. V., Sauvage, B., Haley, C. S., Lloyd, N. D., Llewellyn, E. J., Bernath, P. F., Boone, C. D., Brohede, S., and McElroy, C. T.: Vertical profiles of lightning-

\section{High-ozone layers in the middle and upper troposphere}

T. Trickl et al.

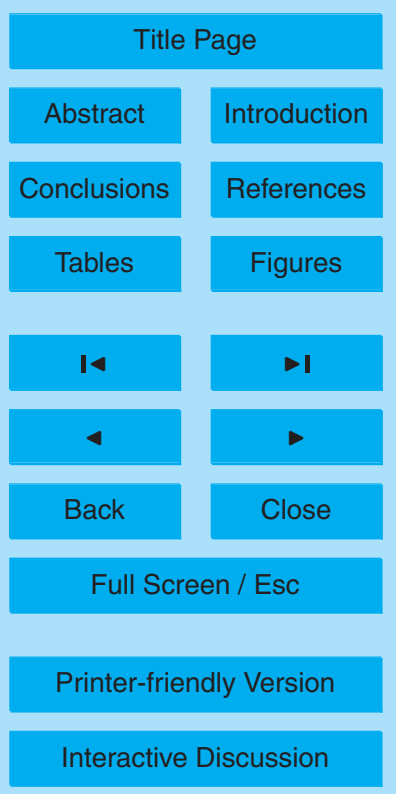


produced $\mathrm{NO}_{2}$ enhancements in the upper troposphere observed by OSIRIS, Atmos. Chem. Phys., 7, 4281-4294, 2007, http://www.atmos-chem-phys.net/7/4281/2007/.

Sprenger, M., Croci Maspoli, M., and Wernli, H.: Tropopause folds and cross-tropopause exchange: A global investigation based upon ECMWF analyses for the time period March 2000 5 to February 2001, J. Geophys. Res., 108, 8518, doi:10.1029/2002JD002587, 2003.

Stohl, A.: A 1-year Lagrangian "climatology" of airstreams in the Northern Hemisphere troposphere and lowermost stratosphere, J. Geophys. Res., 106, 7263-7279, 2001.

Stohl, A. and Seibert, P.: Accuracy of trajectories as determined from the conservation of meteorological tracers, Q. J. Roy. Meteor. Soc., 124, 1465-1484, 1998.

10 Stohl, A. and Thomson, D. J.: A density correction for Lagrangian particle dispersion models, Bound.-Lay. Meteorol., 90, 155-167, 1999.

Stohl, A. and Trickl, T.: A textbook example of long-range transport: Simultaneous observation of ozone maxima of stratospheric and North American origin in the free troposphere over Europe, J. Geophys. Res., 104, 30445-30462, 1999.

Stohl, A., Wotawa, G., Seibert, P., and Kromp-Kolb, H.: Interpolation errors in wind fields as a function of spatial and temporal resolution and their impact on different types of kinematic trajectories, J. Appl. Meteorol., 34, 2149-2165, 1995.

Stohl, A., Hittenberger, M., and Wotawa, G.: Validation of the Lagrangian particle dispersion model FLEXPART against large scale tracer experiments, Atmos. Environ., 32, 4245-4264, 201998.

Stohl, A., Spichtinger-Rakowsky, N., Bonasoni, P., Feldmann, H., Memmesheimer, M., Scheel, H. E., Trickl, T., Hübener, S., Ringer, W., and Mandl, M.: The influence of stratospheric intrusions on alpine ozone concentrations, Atmos. Environ., 34, 1323-1354, 2000.

Stohl, A., Eckhardt, S., Forster, C., James, P., Spichtinger, N., and Seibert, P.: A replacement for simple back trajectory calculations in the interpretation of atmospheric trace substance measurements, Atmos. Environ., 36, 4635-4648, 2002.

Stohl, A., Eckhardt, S., Spichtinger, N., Huntrieser, H., Heland, J., Schlager, H., Wilhelm, S., Arnold, F., and Cooper, O.: A backward modelling study of intercontinental transport using aircraft measurements, J. Geophys. Res., 108, 4370, doi:10.1029/2002JD002862, 2003.

30 Stohl, A., Forster, C., Frank, A., Seibert, P., and Wotawa, G.: Technical note: The Lagrangian particle dispersion model FLEXPART version 6.2, Atmos. Chem. Phys., 5, 2461-2474, 2005, http://www.atmos-chem-phys.net/5/2461/2005/.

Stohl, A., Forster, C., Huntrieser, H., Mannstein, H., McMillan, W. W., Petzold, A., Schlager, 
H., and Weinzierl, B.: Aircraft measurements over Europe of an air pollution plume from Southeast Asia - aerosol and chemical characterization, Atmos. Chem. Phys., 7, 913-937, 2007, http://www.atmos-chem-phys.net/7/913/2007/.

Thouret, V., Cammas, J.-P., Sauvage, B., Athier, G., Zbinden, R., Nédélec, P., Simon, P., and

$5 \quad$ Karcher, F.: Tropopause referenced ozone climatology and inter-annual variability (19942003) from the MOZAIC programme, Atmos. Chem. Phys., 6, 1033-1051, 2006, http://www.atmos-chem-phys.net/6/1033/2006/.

Trickl, T., Cooper, O. C., Eisele, H., James, P., Mücke, R., and Stohl, A.: Intercontinental transport and its influence on the ozone concentrations over central Europe: Three case studies, J. Geophys. Res., 108, 8530, doi:10.1029/2002JD002735, 2003.

Trickl, T., Feldmann, H., Kanter, H.-J., Scheel, H.-E., Sprenger, M., Stohl, A., and Wernli, H.: Forecasted deep stratospheric intrusions over Central Europe: case studies and climatologies, Atmos. Chem. Phys. Discuss., 9, 2223-2288, 2009a, http://www.atmos-chem-phys-discuss.net/9/2223/2009/.

15 Trickl, T., Forster, C., James, P., Scheel, H., and Stohl, A.: Low Central European Ozone and $\mathrm{CO}$ Import from the Subtropical North Atlantic, in preparation, 2009b.

Val Martin, M., Honrath, R. E., Owen, R. C., Pfister, G. Fialho, P., and Barata, F.: Significant enhancements of nitrogen oxides, black carbon, and ozone in the North Atlantic lower free troposphere resulting from North American boreal wild fires, J. Geophys. Res., 111, Dd23S60, 20 doi:10.1029/2006JD007530, 2006.

Vogelmann, $\mathrm{H}$. and Trickl, T.: Wide-range sounding of free-tropospheric water vapor with a differential-absorption lidar (DIAL) at a high-altitude station, Appl. Optics, 47, 2116-2132, 2008.

VOTALP II: Vertical Ozone Transport in the Alps II, Final Report for the European Union, Contract Nr.: ENV4 CT970413, Reporting Period 1/3/1998-29/2/2000, H. Kromp-Kolb, Coordinator, Universität für Bodenkultur Wien (Austria), Institut für Meteorologie und Physik, http://www.boku.ac.at/imp/votalp/, 96 pp., 2000.

Zanis, P., Trickl, T., Stohl, A., Wernli, H., Cooper, O., Zerefos, C., Gaeggeler, H., Schnabel, C., Tobler, L., Kubik, P. W., Priller, A., Scheel, H. E., Kanter, H. J., Cristofanelli, P., Forster, C., James, P., Gerasopoulos, E., Delcloo, A., Papayannis, A., and Claude, H.: Forecast, observation and modelling of a deep stratospheric intrusion event over Europe, Atmos. Chem. Phys., 3, 763-777, 2003, http://www.atmos-chem-phys.net/3/763/2003/.

High-ozone layers in the middle and upper troposphere

T. Trickl et al.

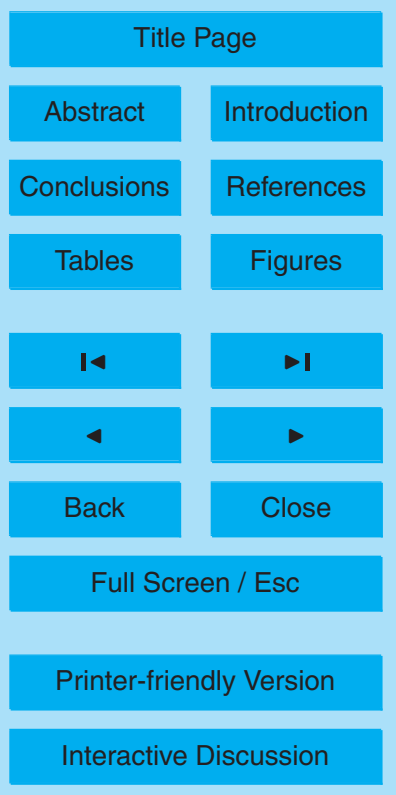




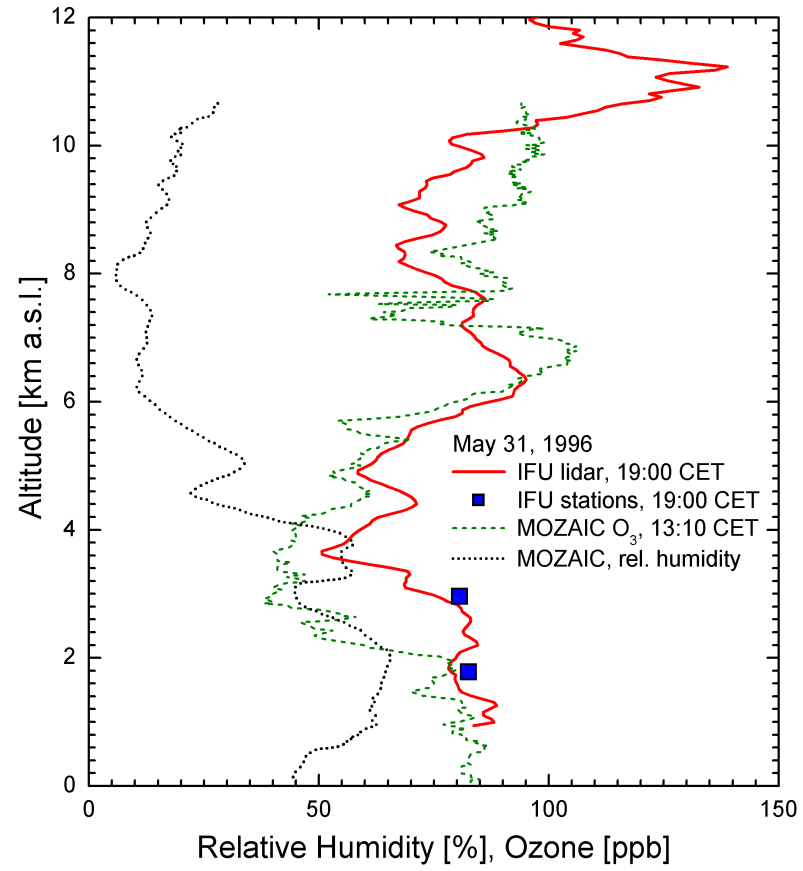

Fig. 1. Ozone measurement at IMK-IFU (Garmisch-Partenkirchen) and MOZAIC ozone and humidity profiles for the departure of a MOZAIC aeroplane from Frankfurt (Germany); see Fig. 12 in (Trickl et al., 2003). The ozone mixing ratios of the nearby summit stations Wank (1780 ma.s.I.) and Zugspitze $(2962 \mathrm{~m})$ are also given for comparision. The ozone peak at $11 \mathrm{~km}$ is a temporary feature. The times are given in Central European Time (CET).
ACPD

9, 3113-3166, 2009

High-ozone layers in the middle and upper troposphere

T. Trickl et al.

Title Page

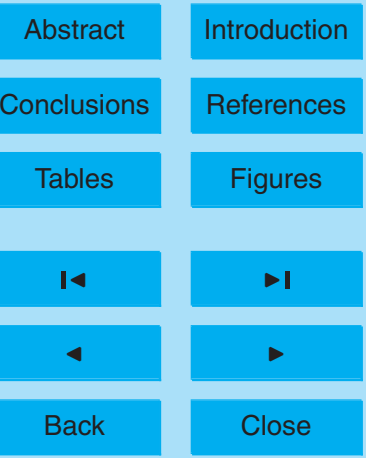

Full Screen / Esc

Printer-friendly Version

Interactive Discussion 
May 31, 1996, 7-17 CET, 5-7 km a.s.I.
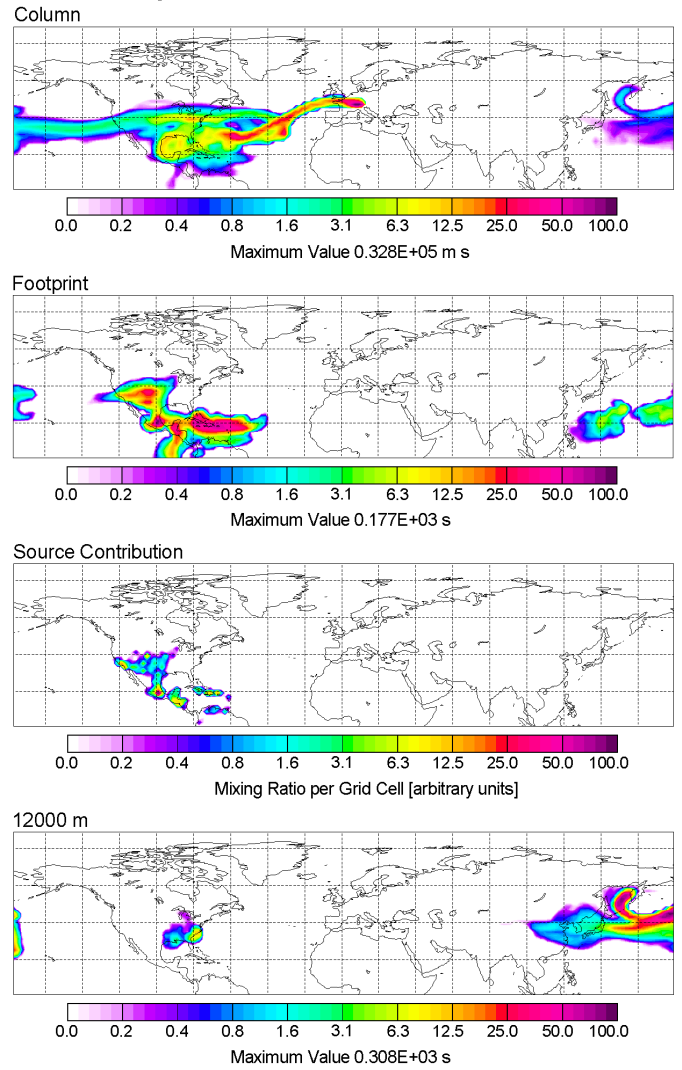

Fig. 2. FLEXPART fifteen-day backward (or retroplume) simulation for 31 May 1996, 07:00 to 17:00 CET and 5 to $7 \mathrm{~km}$ a.s.I. above IMK-IFU; the PBL source contribution was determined by folding the footprint emission sensitivity with $\mathrm{NO}_{\mathrm{x}}$ emissions from the EDGAR inventory.

\section{ACPD}

9, 3113-3166, 2009

High-ozone layers in the middle and upper troposphere

T. Trickl et al.

Title Page

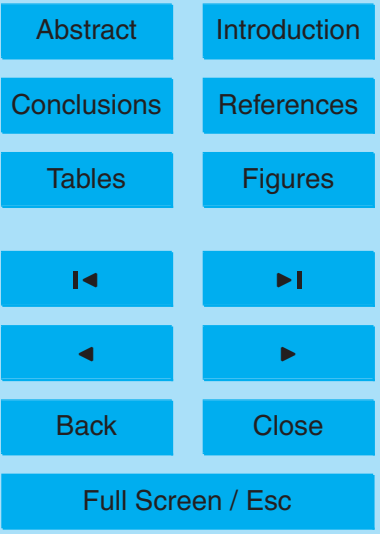

Printer-friendly Version

Interactive Discussion 
May 31, 1996, 7-17 CET, 7-10 km a.s.I.
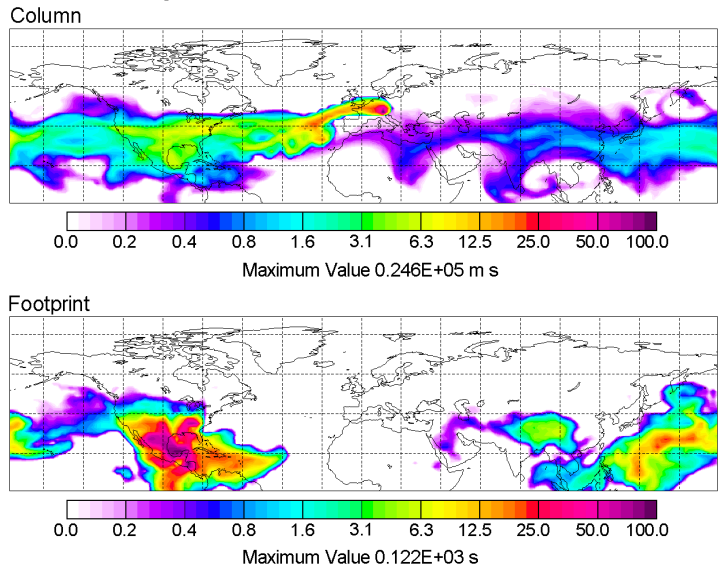

Source Contribution
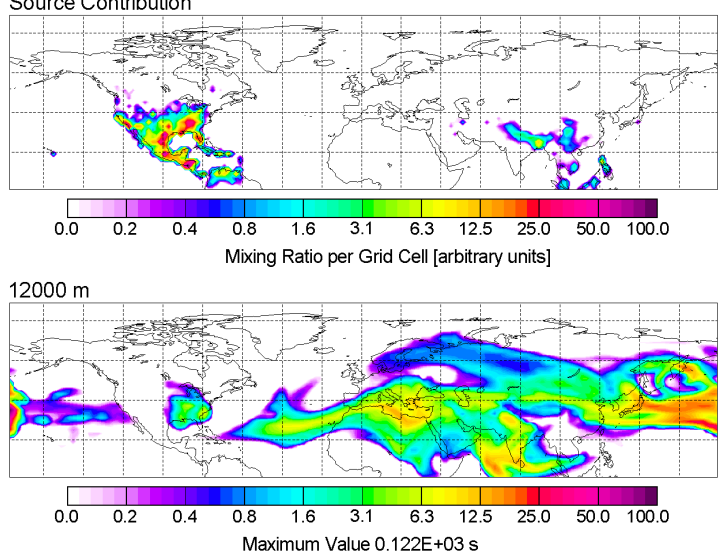

Fig. 3. Same as Fig. 2, but for the altitude range 7 to $10 \mathrm{~km}$ a.s.I. above IMK-IFU.

\section{ACPD}

9, 3113-3166, 2009

High-ozone layers in the middle and upper troposphere

T. Trickl et al.

Title Page

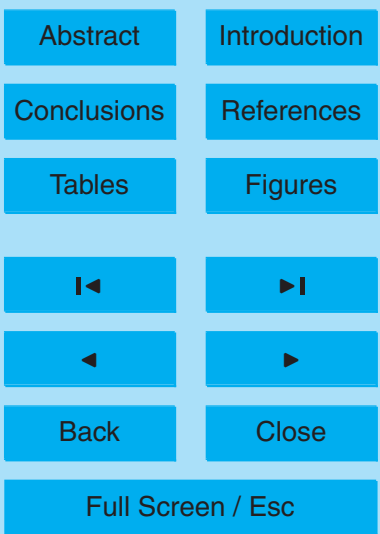

Printer-friendly Version

Interactive Discussion 


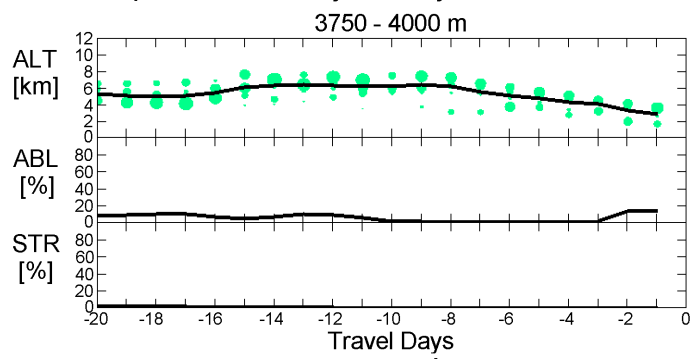

\section{ACPD}

9, 3113-3166, 2009

\section{High-ozone layers in the middle and upper troposphere}

T. Trickl et al.
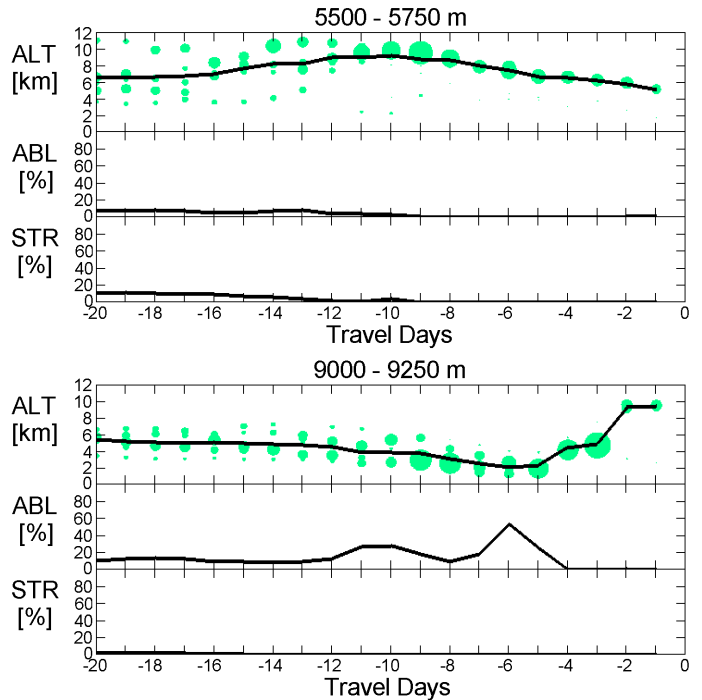

Title Page

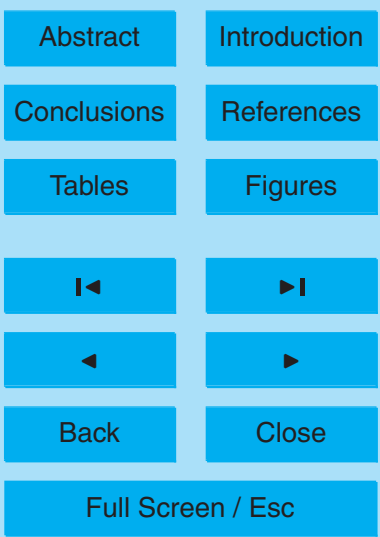

Fig. 4. Retroplume summaries for three selected altitude ranges above GarmischPartenkirchen initiated at the time of the lidar measurement in Fig. 1. The boxes show the approximate vertical position (ALT: altitude) of the backward plume during the preceding 20 days and the relative single-day contributions from the PBL (ABL) and the stratosphere (STR). For details see Sect. 2.2. 
May 31, 1996, 19 CET, Impact of Continental Emissions

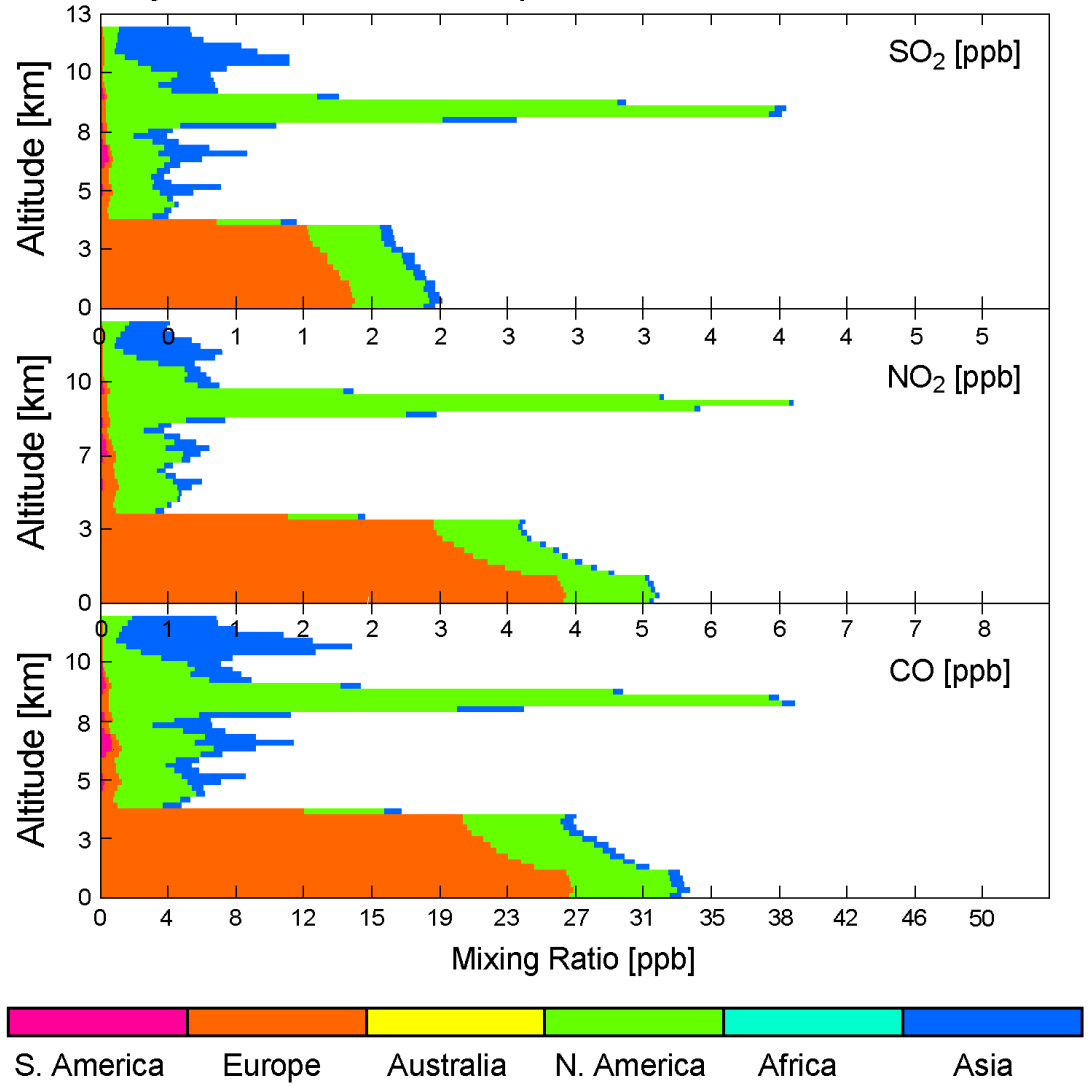

Fig. 5. Vertical distribution of emission tracers from the different source continents above Garmisch-Partenkirchen, simulated for the time of the lidar measurement on 31 May 1996, shown in Fig. 1. Please, note that the numbers in the mixing-ratio scales are just rounded to the next integer value.
ACPD

9, 3113-3166, 2009

High-ozone layers in the middle and upper troposphere

T. Trickl et al.

Title Page

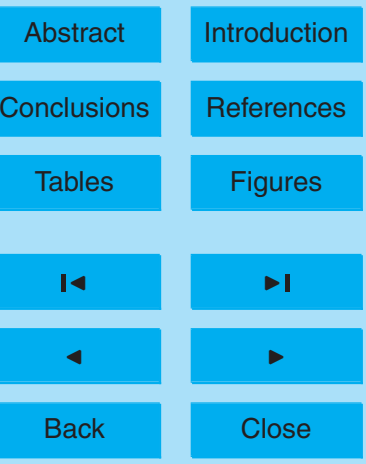

Full Screen / Esc

Printer-friendly Version

Interactive Discussion 

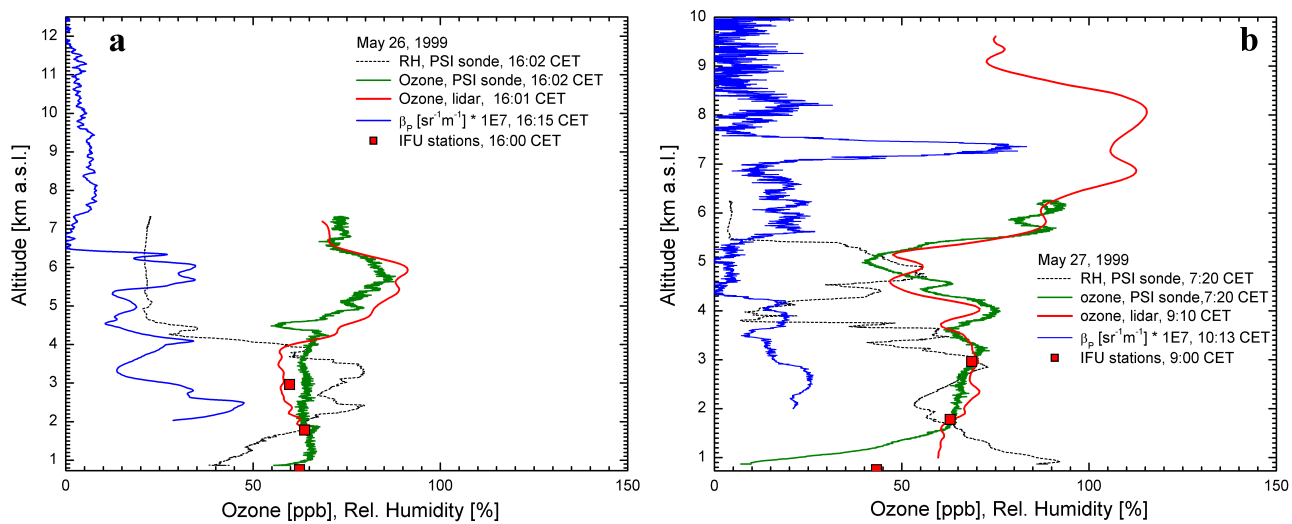

ACPD

9, 3113-3166, 2009

High-ozone layers in the middle and upper troposphere

T. Trickl et al.
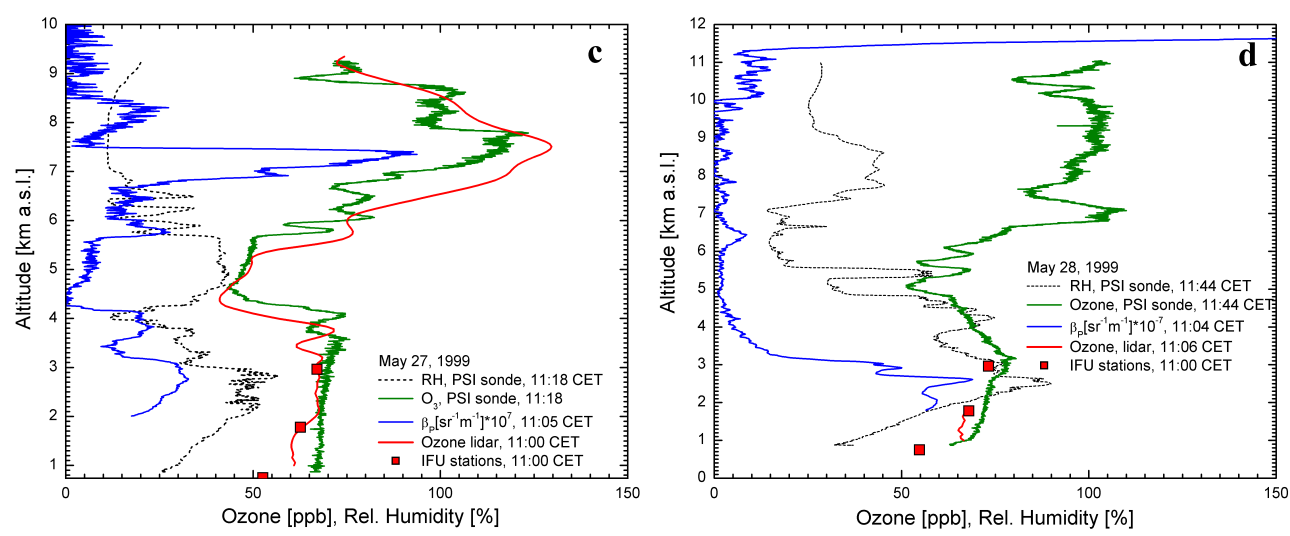

Title Page

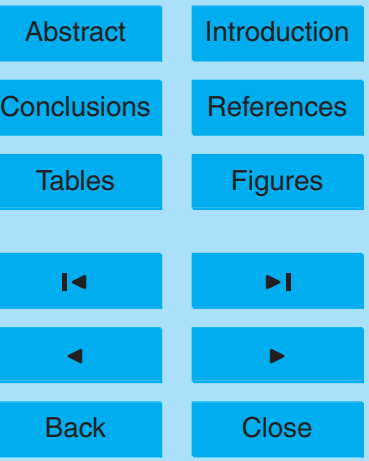

Full Screen / Esc

Fig. 6. Examples of lidar, sonde and station measurements from the VOTALP II "Munich" field campaign, (a) 26 May 1999, around 16:00 CET; (b) in the morning of 27 May 1999; (c) around noon on 27 May 1999; (d) before noon on 28 May 1999. Shown are ozone (lidar, PSI sonde, stations), relative humidity (PSI sonde) and the aerosol backscatter coefficient $\beta_{P}$ derived from the measurements with the "NDACC" aerosol lidar at large elevation angles of at least $45^{\circ}$. 
May 27, 1999, 5-15 CET, 5-9 km a.s.I.
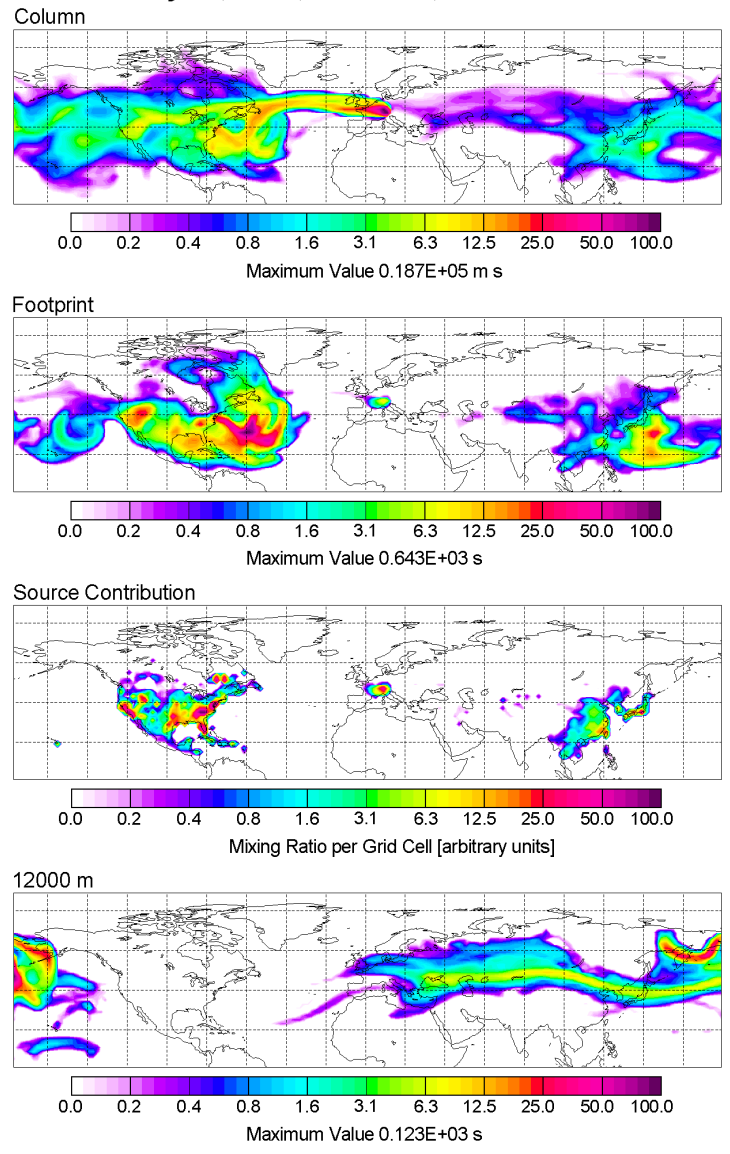

Fig. 7. Fifteen-day backward simulation with FLEXPART for 27 May 1999, between 05:00 and 15:00 CET, corresponding to the measurements in Fig. $6 \mathrm{~b}$ and $\mathrm{c}$.

\section{ACPD}

9, 3113-3166, 2009

High-ozone layers in the middle and upper troposphere

T. Trickl et al.

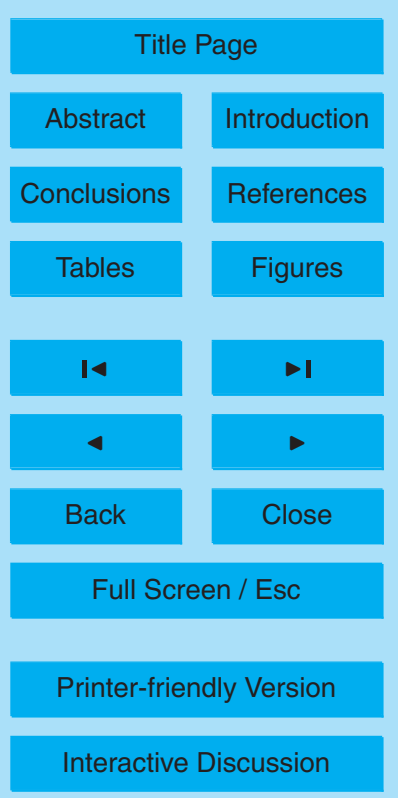

(c) $\underset{\mathrm{BY}}{(\mathrm{P}}$ 


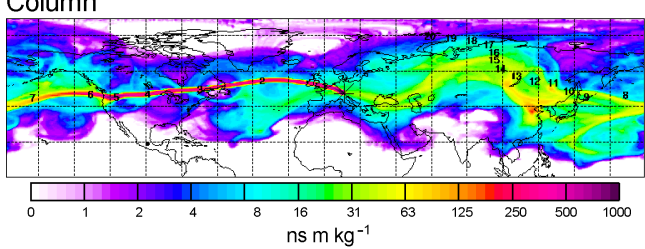

\section{9, 3113-3166, 2009}

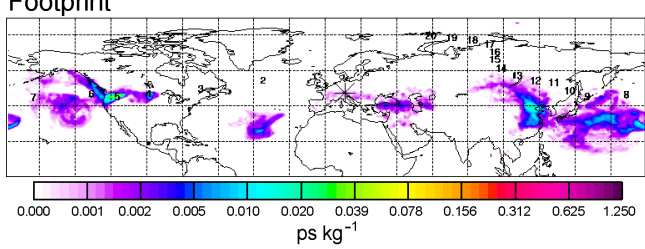

Retroplume Analysis
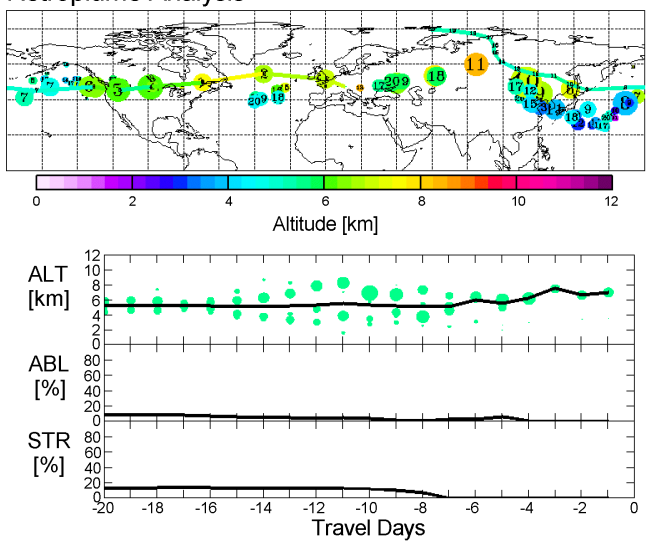

High-ozone layers in the middle and upper troposphere

T. Trickl et al.

Title Page

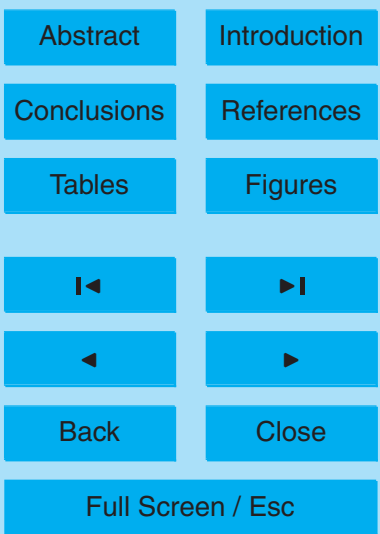

Fig. 8. Twenty-day backward simulations for the lidar measurements in Fig. 6a (26 May 1999), initiated in the altitude range between 5750 and $6000 \mathrm{~m}$ : Column-integrated emission sensitivity, footprint emission sensitivity and retroplume summary. For details see Sect. 2.2. 
May 26, 1999, 16 CET, Impact of Continental Emissions

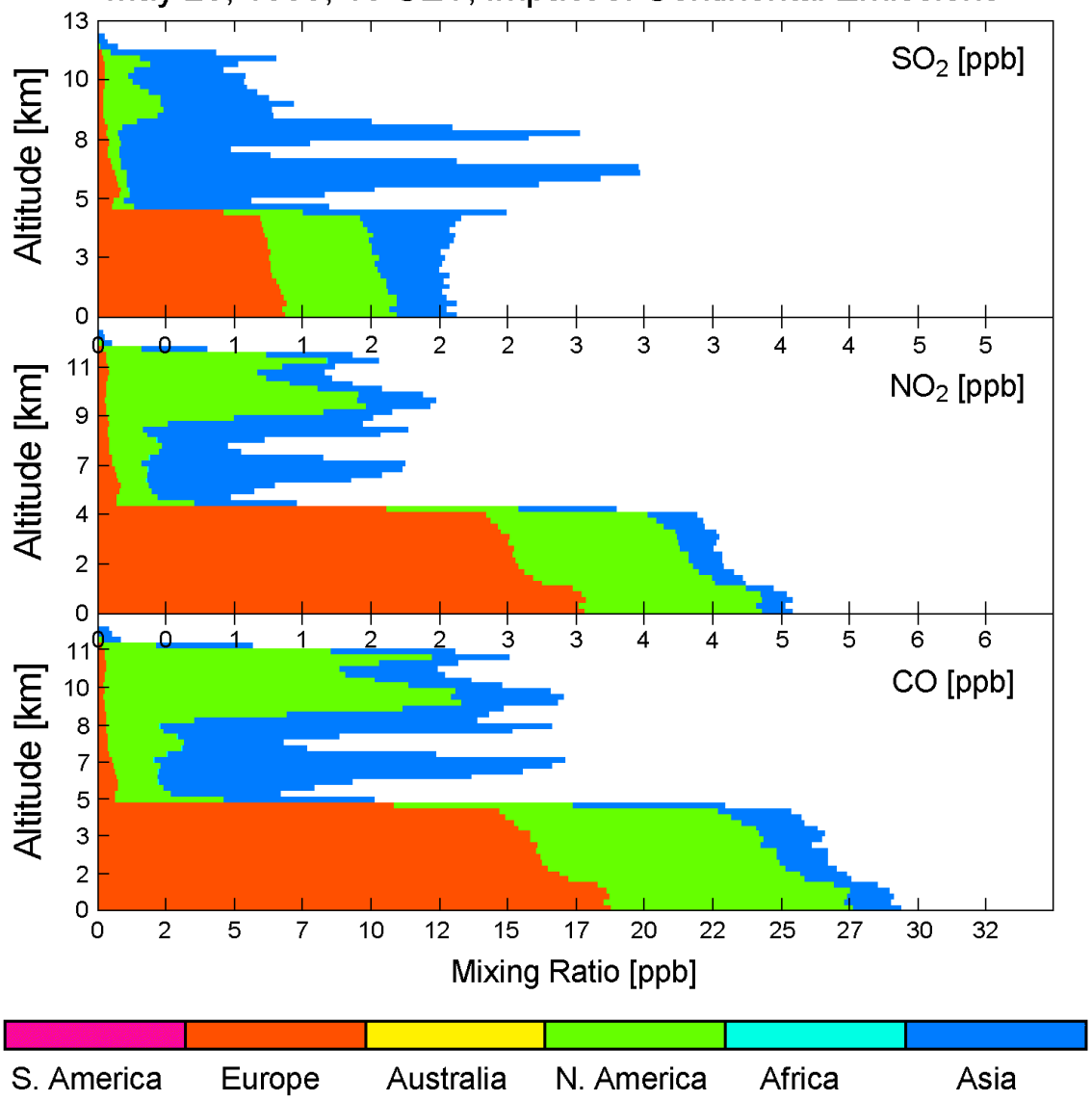

Fig. 9. Vertical distribution of emission tracers from the different source continents above Garmisch-Partenkirchen, simulated for the time of the lidar measurement on 26 May 1999, shown in Fig. 6a; a pronounced Asian influence is demonstrated for altitudes above $5 \mathrm{~km}$.
ACPD

9, 3113-3166, 2009

High-ozone layers in the middle and upper troposphere

T. Trickl et al.

\section{Title Page}

\section{Abstract}

Introduction

Conclusions

References

Tables

Figures

14

4

Back

Close

Full Screen / Esc

Printer-friendly Version

Interactive Discussion 
Retroplume Summary for May 27, 1999, 11 CET

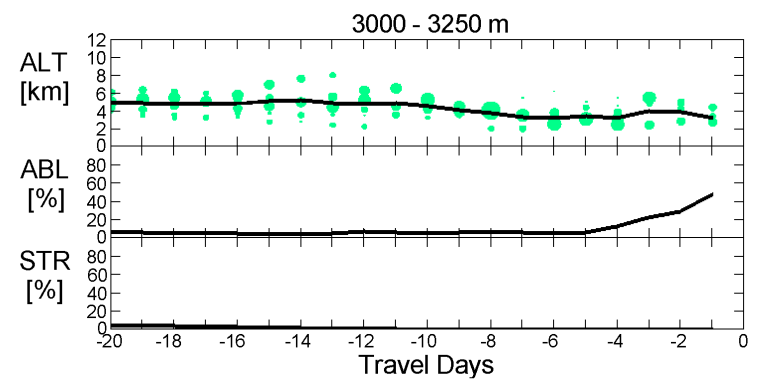

ACPD

9, 3113-3166, 2009

\section{High-ozone layers in} the middle and upper troposphere

T. Trickl et al.

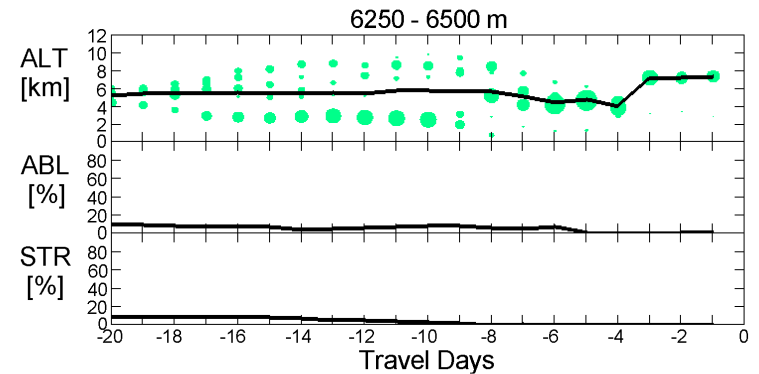

Title Page
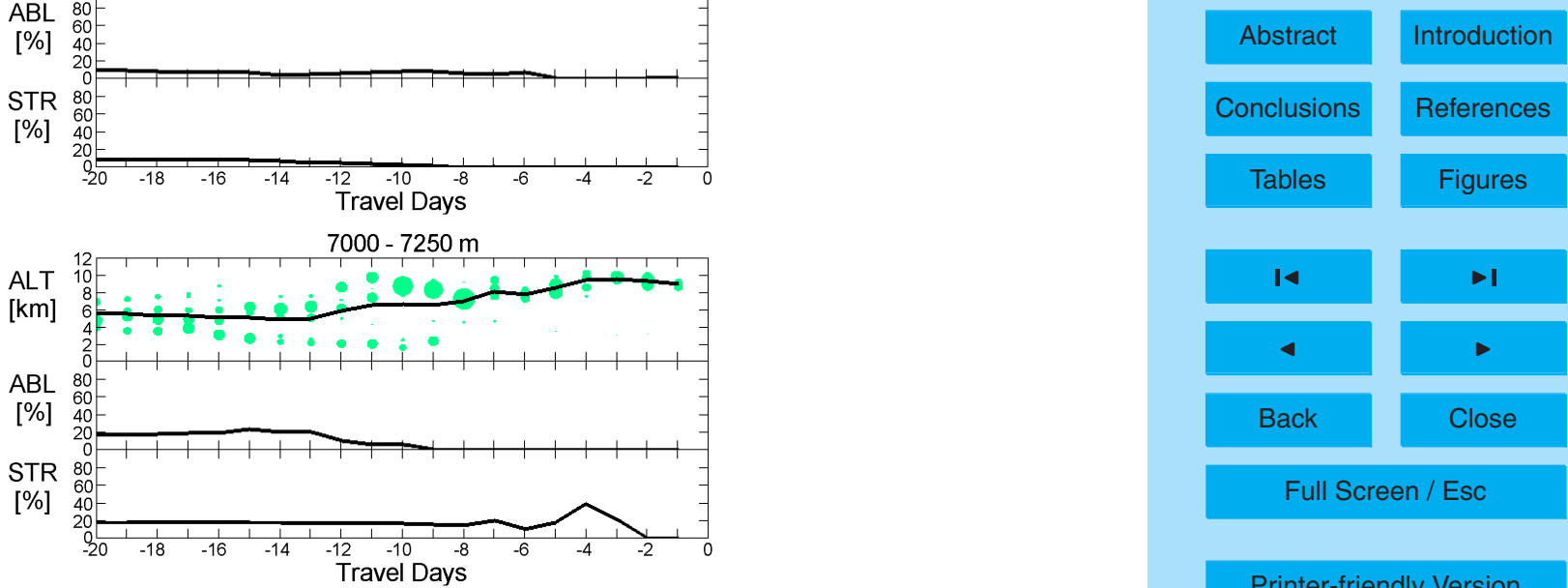

Printer-friendly Version

Fig. 10. Retroplume time-height sections for three selected altitude ranges above GarmischPartenkirchen initiated at the time of the lidar measurement in Fig. 6c; for details see Fig. 4. The simulations for Fig. $6 \mathrm{~b}$ look similar. For details see Sect. 2.2. 
May 27, 1999, 11 CET, Impact of Continental Emissions

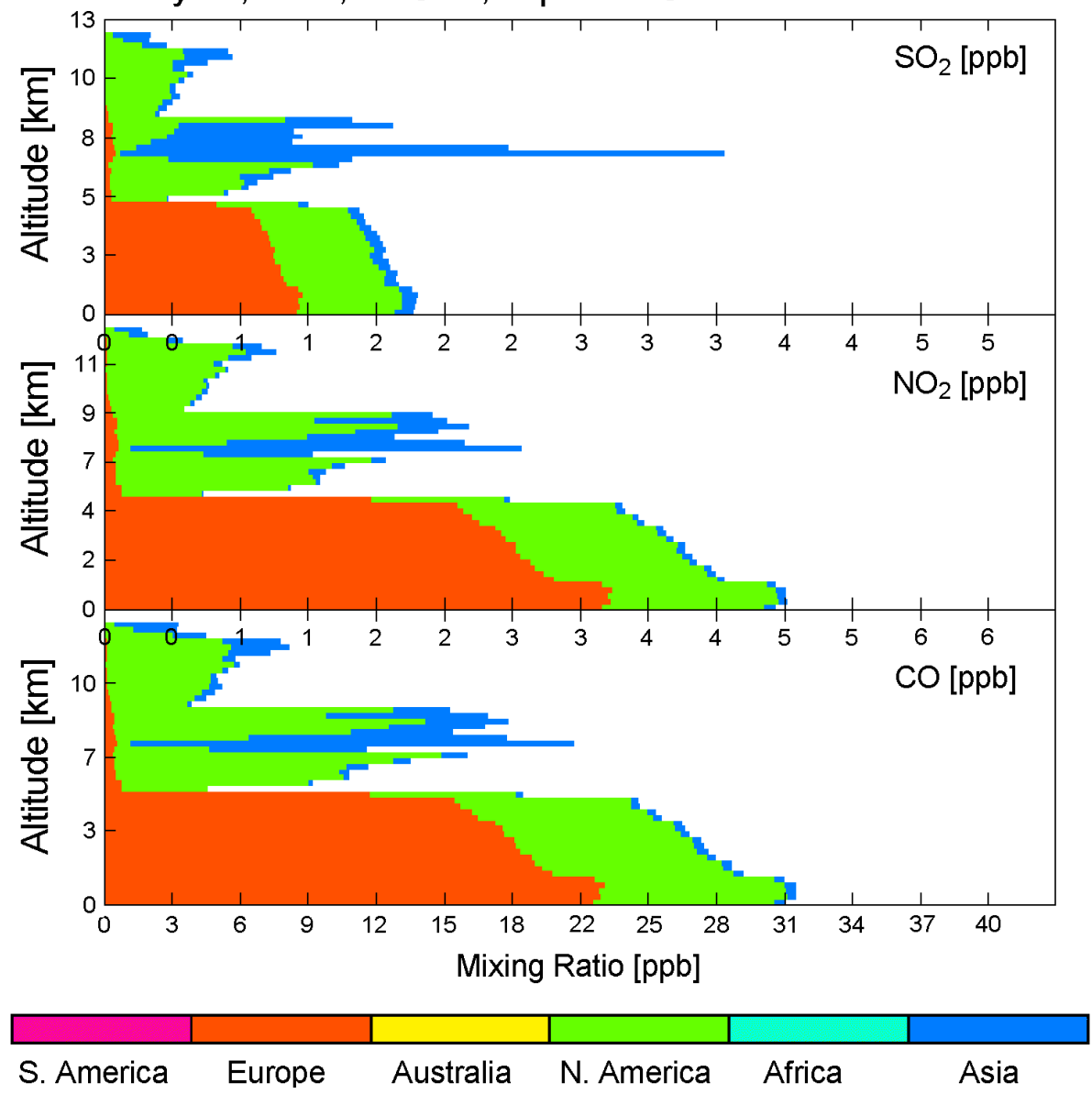

ACPD

9, 3113-3166, 2009

High-ozone layers in the middle and upper troposphere

T. Trickl et al.

Title Page

Abstract

Introduction

Conclusions

References

Tables

Figures

14

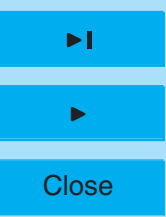

Back

Close

Full Screen / Esc

Printer-friendly Version

Interactive Discussion

Fig. 11. Vertical distribution of tracers from the different source continents simulated for the lidar measurement on 27 May 1999, shown in Fig. 6c. 


\section{ACPD}

\section{9, 3113-3166, 2009}

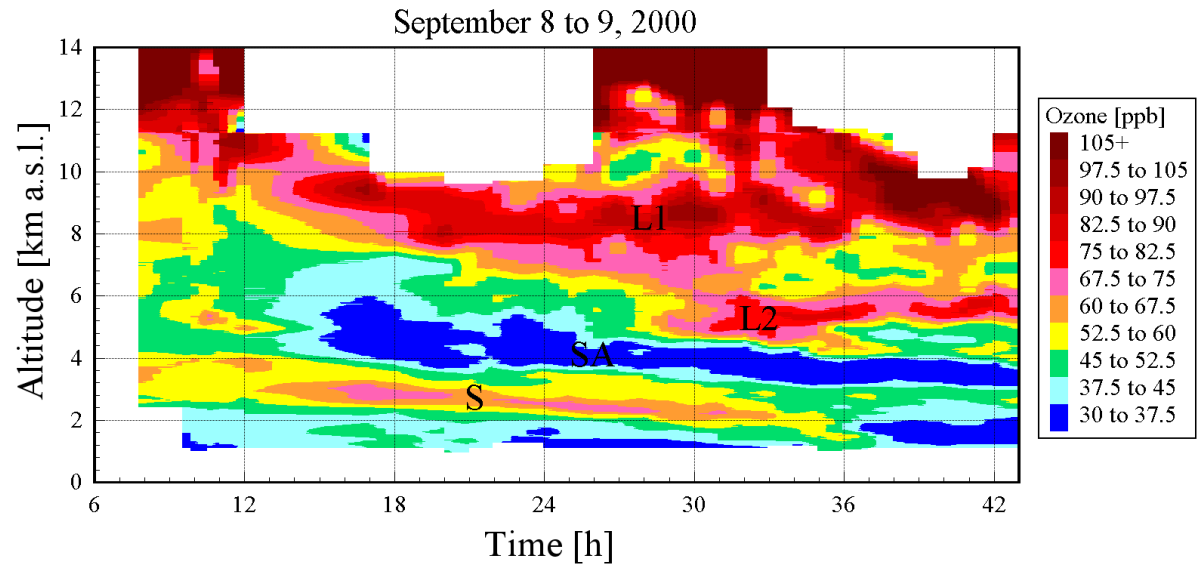

\section{High-ozone layers in the middle and upper troposphere}

T. Trickl et al.

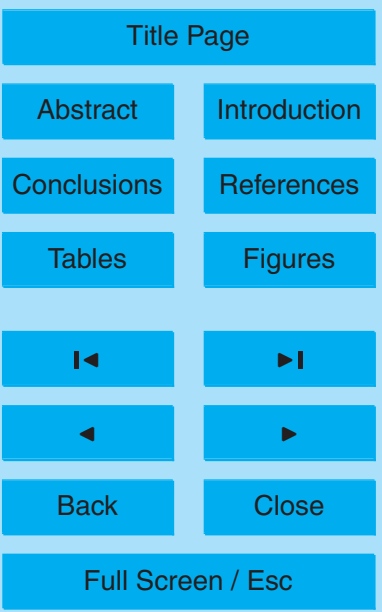

Fig. 12. First two days from the lidar series 8 to 12 September 2000 , during the early phase of a high-pressure period (full series: Trickl et al., 2003, Fig. 13); S marks a stratospheric air intrusion, SA air from subtropical Atlantic, the layers marked with the labels L1 and L2 are discussed in the text. The time scale is given with respect to 00:00 CET on 8 September.

Printer-friendly Version

Interactive Discussion 

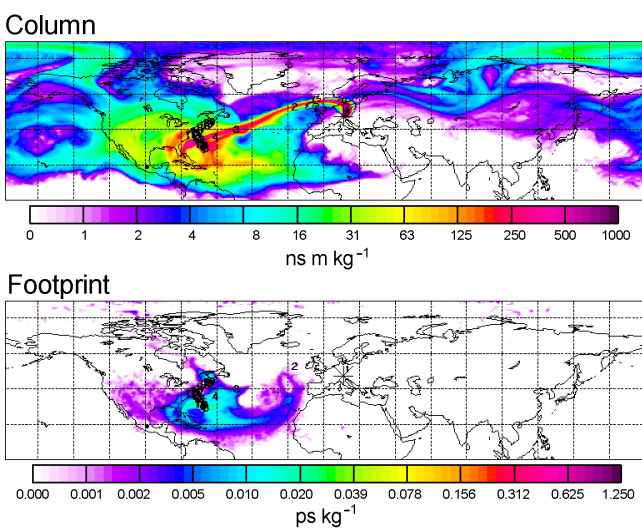

Retroplume Analysis
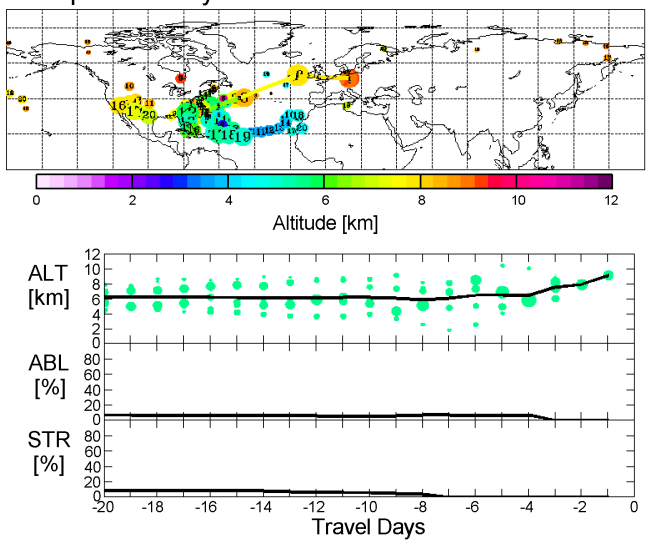

Fig. 13. Twenty-day backward simulations for 9 September 2000, 10:00 CET, initiated in the altitude range between 7750 and $8000 \mathrm{~m}$ : Column-integrated emission sensitivity, footprint emission sensitivity and retroplume summary; there is some indication that the enhanced ozone in this altitude range is due to STT. For details see Sect. 2.2.

\section{ACPD}

9, 3113-3166, 2009

High-ozone layers in the middle and upper troposphere

T. Trickl et al.

Title Page

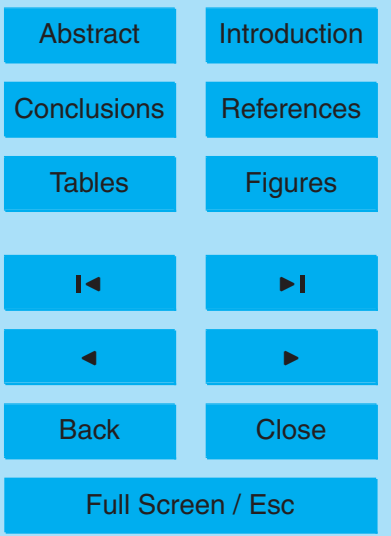

Printer-friendly Version

Interactive Discussion 


\section{ACPD}

\section{9, 3113-3166, 2009}

High-ozone layers in the middle and upper troposphere

July 21 to 24,2001

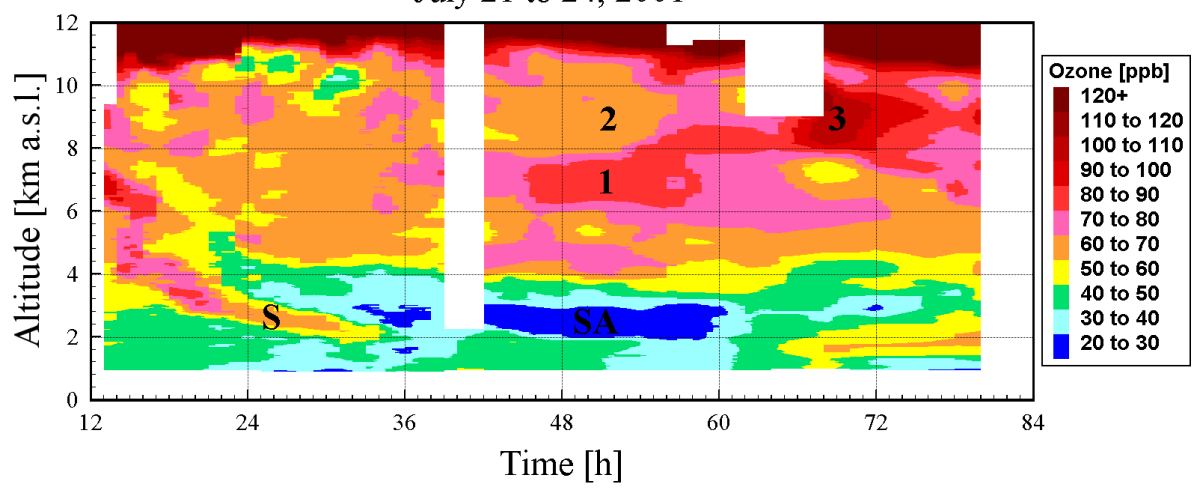

Fig. 14. Ozone sounding series in July 2001 at the beginning of a high-pressure period; $S$ marks a stratospheric air intrusion, SA air from subtropical Atlantic, the layers marked with the labels L1, L2 and L3 are discussed in the text. The time scale is given with respect to 00:00 CET on 21 July.
T. Trickl et al.

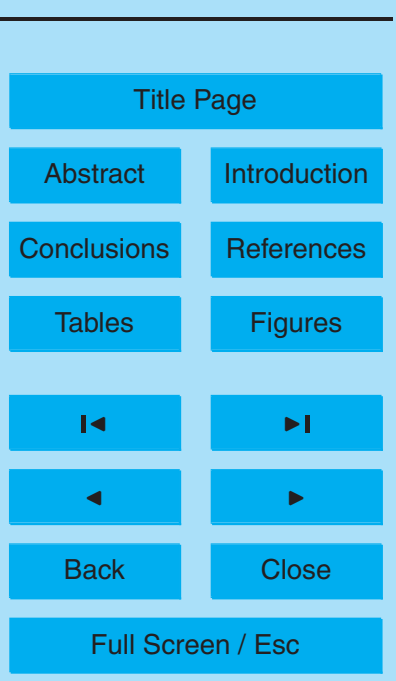

Printer-friendly Version

Interactive Discussion 


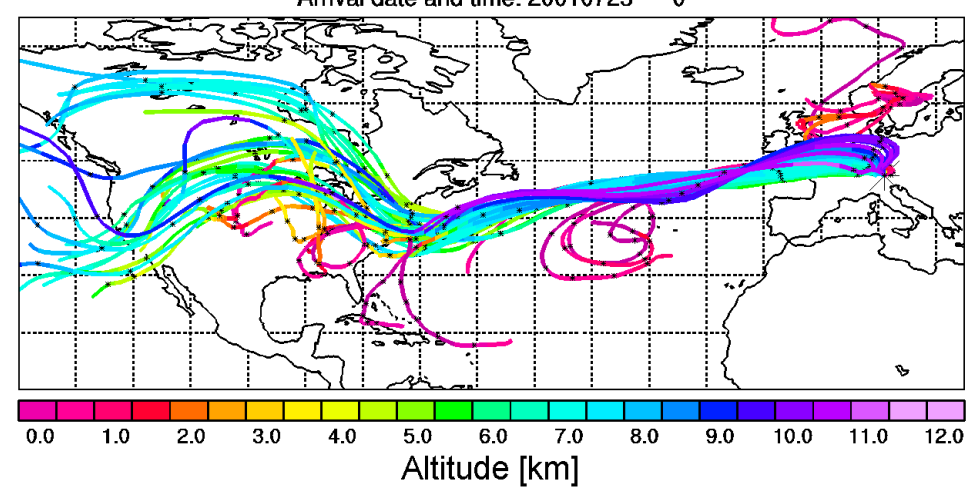

\section{9, 3113-3166, 2009}

High-ozone layers in the middle and upper troposphere

T. Trickl et al.

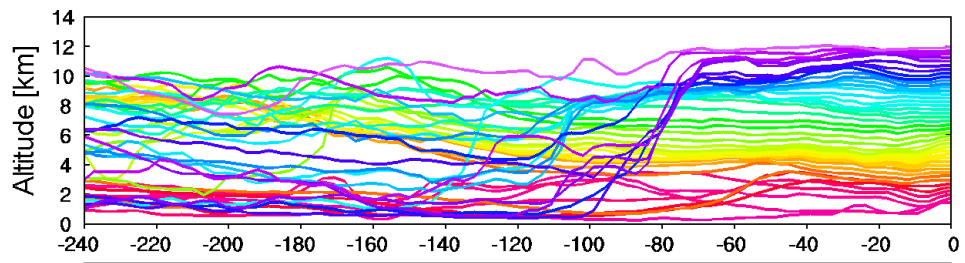

Title Page
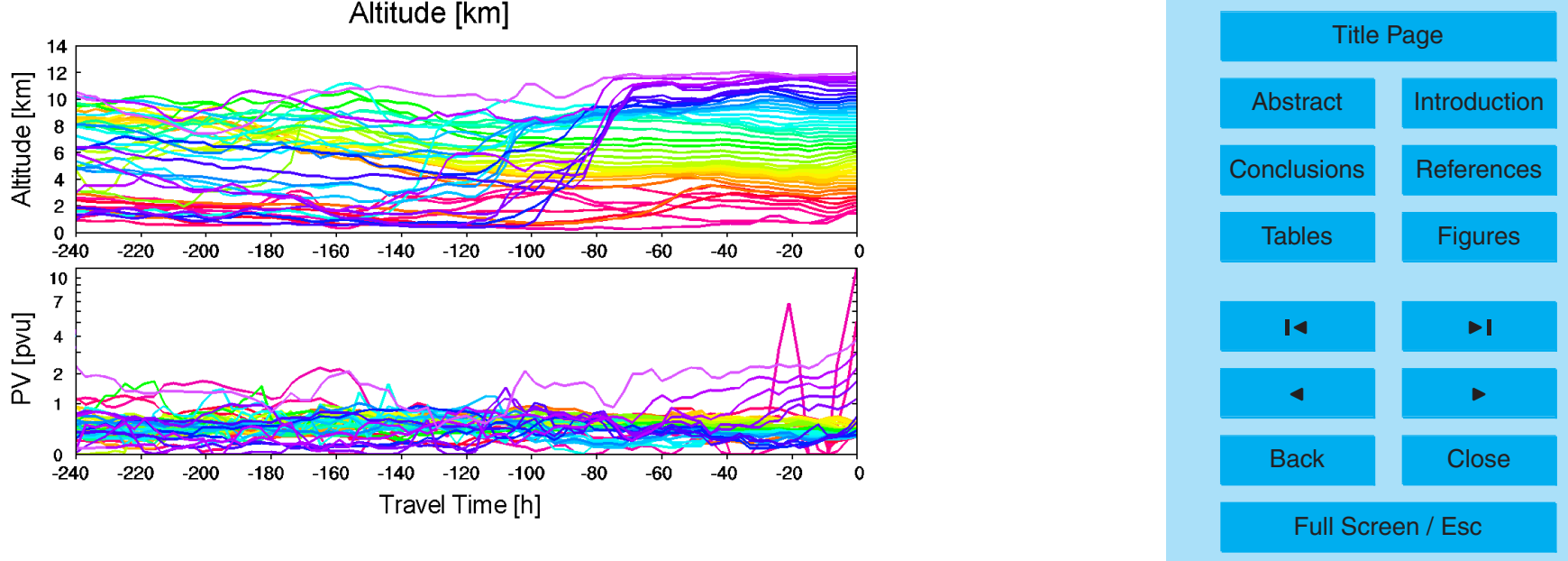

Fig. 15. Ten-day FLEXTRA backward trajectories initiated above Garmisch-Partenkirchen on 23 July 2001, 01:00 CET (corresponding to labels 1 and 2 in Fig. 14); the colour code in the upper panel describes the altitude at a given time. In the lower two panels it indicates the altitude at the location of Garmisch-Partenkirchen $(t=0)$. The asterisks on the individual trajectories mark the 00:00 UTC positions. 
Arrival date and time: 20010723180000
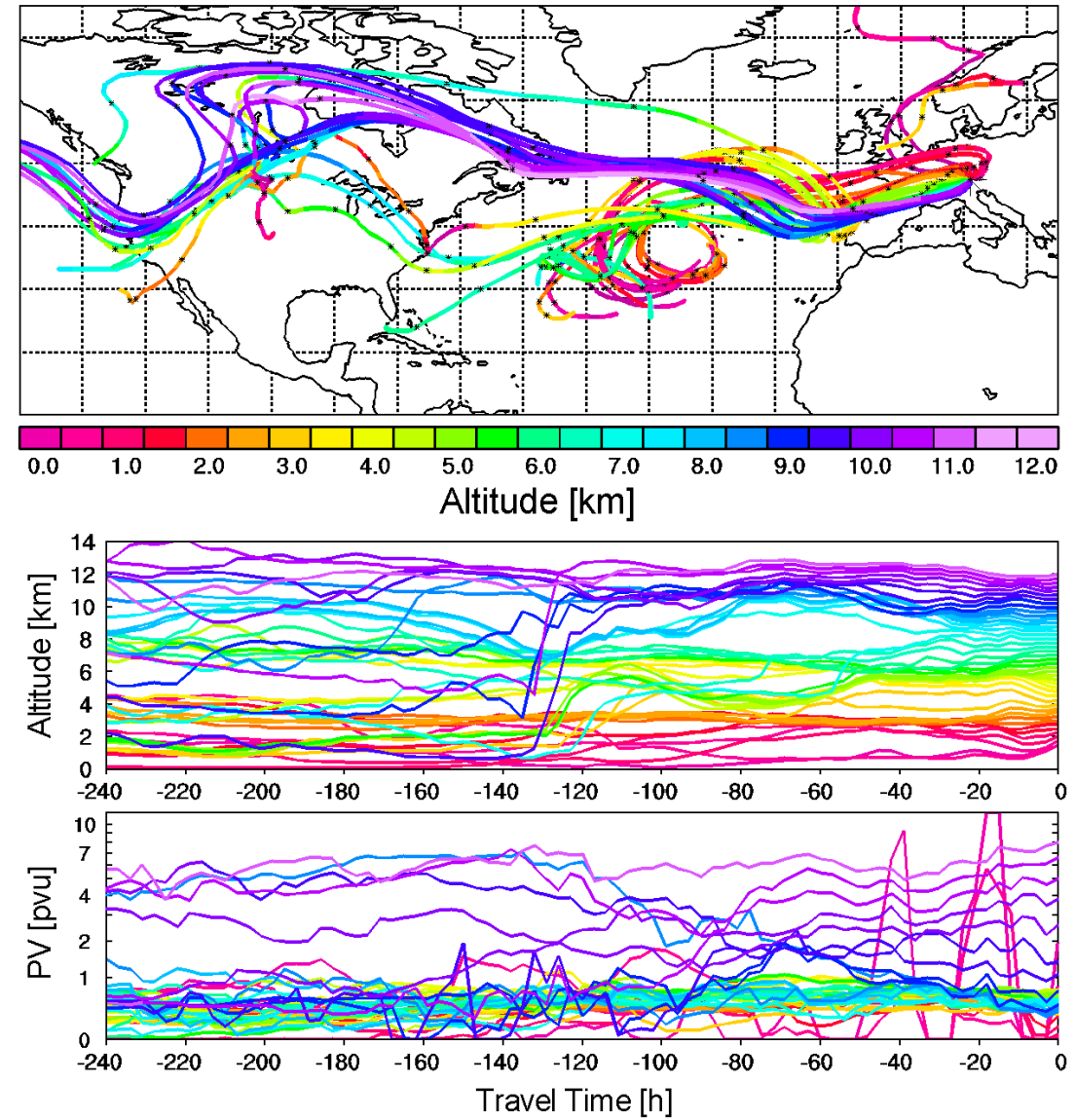

Fig. 16. Same as Fig. 15, but for 23 July 2001, 19:00 CET (corresponding to label 3 in Fig. 14); some of the upper-tropospheric trajectories reach altitudes above $12 \mathrm{~km}$ during the earliest period.

\section{ACPD}

\section{9, 3113-3166, 2009}

High-ozone layers in the middle and upper troposphere

T. Trickl et al.

\section{Title Page}
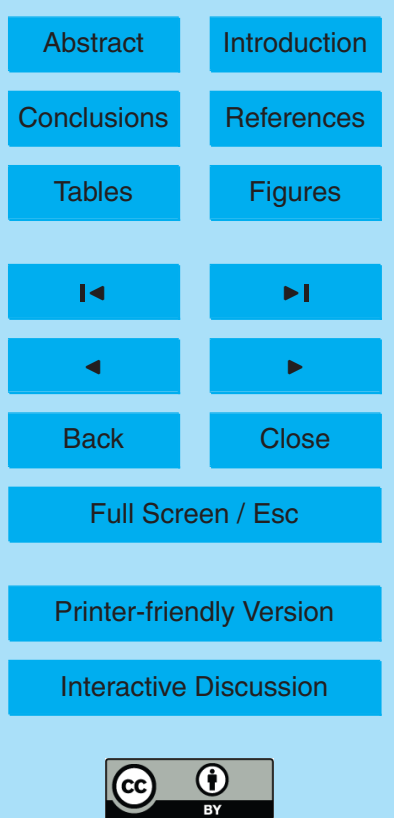

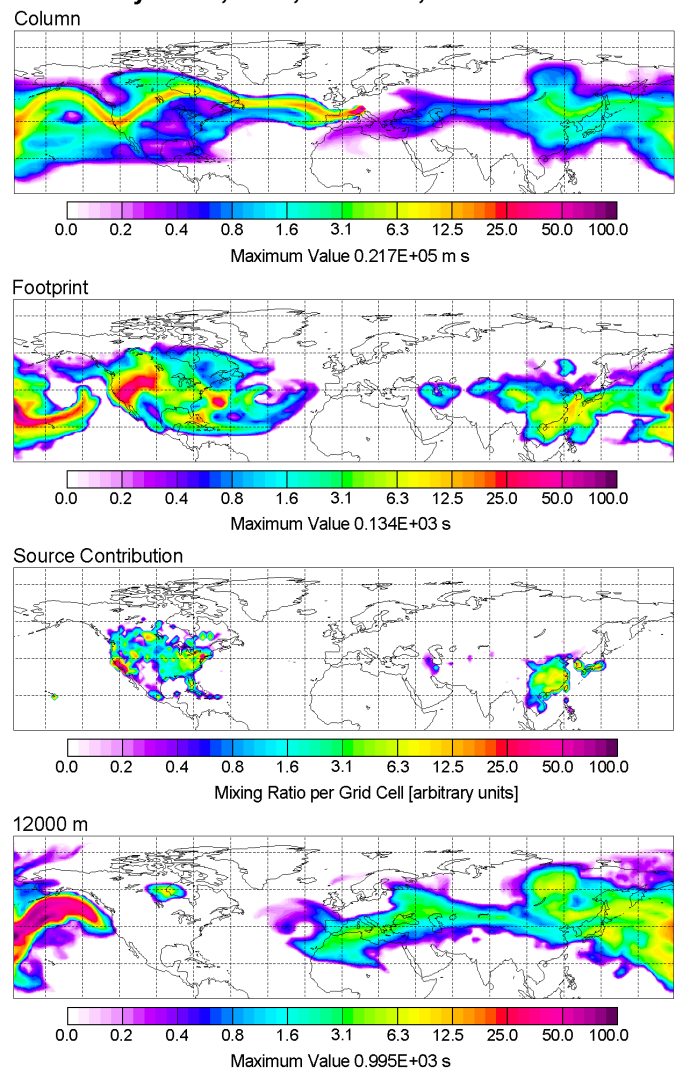

Fig. 17. FLEXPART fifteen-day backward simulation for retroplumes released between 23 July 2001, 18:00 CET, to 24 July 2001, 03:00 CET, and between 8 and $10 \mathrm{~km}$ a.s.I. above GarmischPartenkirchen (layer L3 in Fig. 14).
ACPD

9, 3113-3166, 2009

High-ozone layers in the middle and upper troposphere

T. Trickl et al.

Title Page

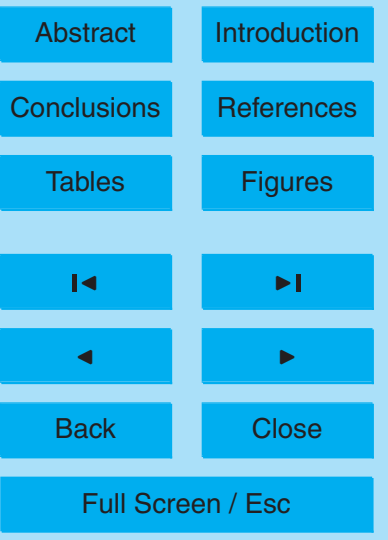

Printer-friendly Version

Interactive Discussion 


\section{ACPD}

\section{9, 3113-3166, 2009}

\section{High-ozone layers in the middle and upper troposphere}

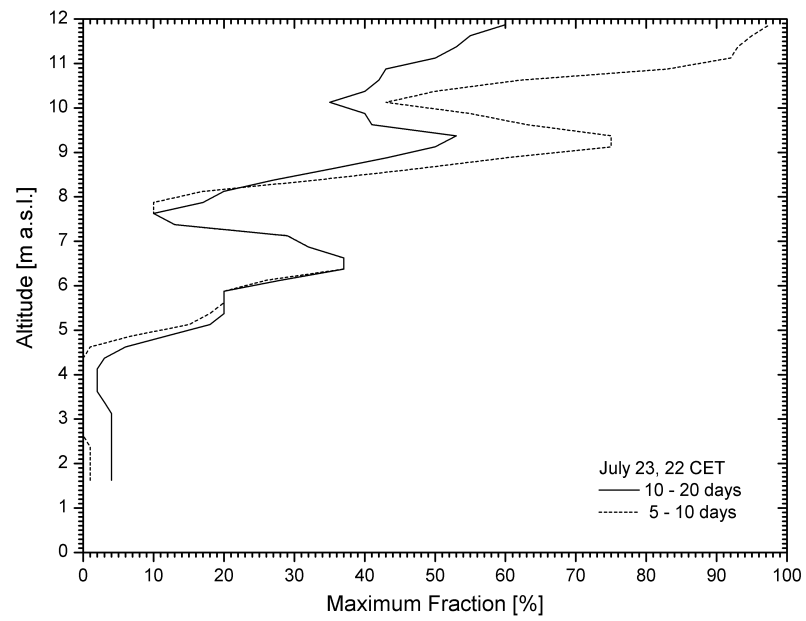

T. Trickl et al.

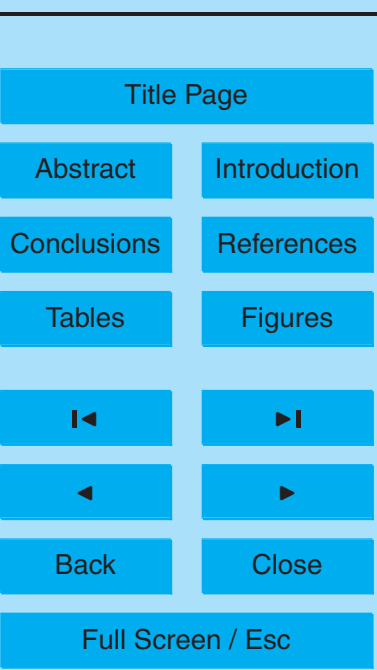

Printer-friendly Version

Fig. 18. Vertical distribution of the maximum stratospheric fraction in the retroplume calculated for 23 July, 22:00 CET, for two different backward time periods. 


\section{ACPD}

\section{9, 3113-3166, 2009}

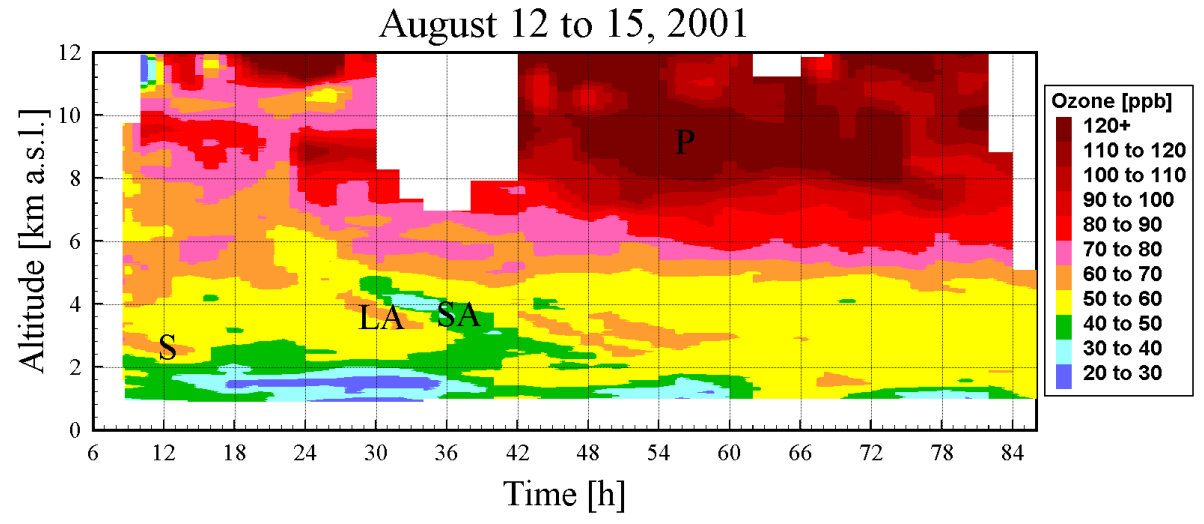

Fig. 19. Lidar measurements on 12 to 15 August 2001, during the onset of a high-pressure period; the typical three-layer pattern with a stratospheric intrusion (S) at the bottom, low-ozone air from the subtropical Atlantic (SA) above it and air of trans-Atlantic origin in the middle and upper troposphere is, again, observed, but the layers are less clearly distinguishable. LA means long-range advection from high altitudes above the northern Pacific. The time scale is given with respect to 00:00 CET on 12 August.

\section{High-ozone layers in the middle and upper troposphere}

T. Trickl et al.

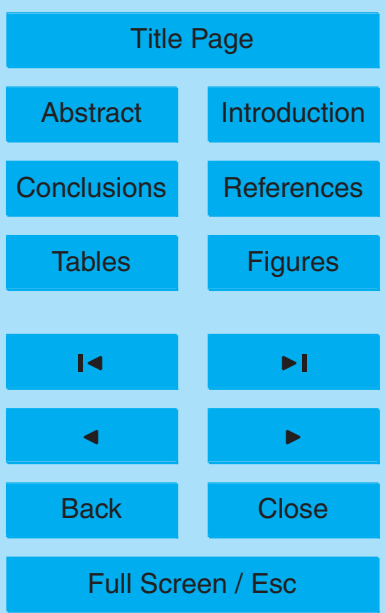

Printer-friendly Version

Interactive Discussion 
Column

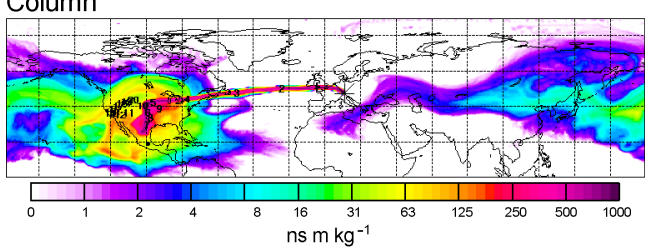

Footprint

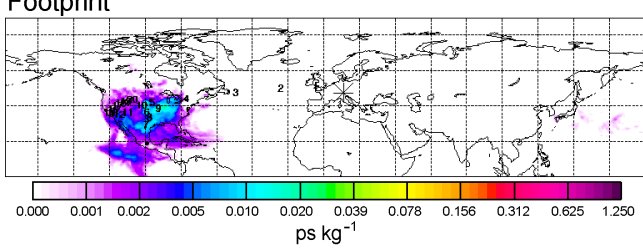

Retroplume Analysis

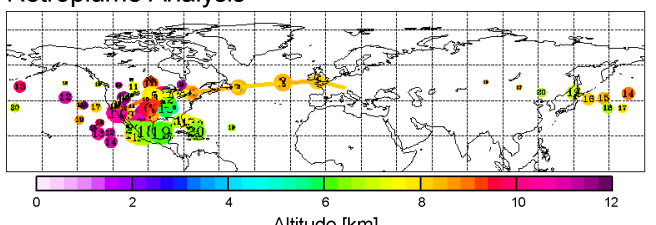

Altitude $[\mathrm{km}]$

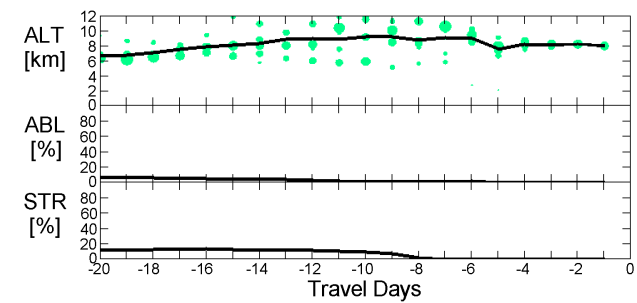

Fig. 20. Twenty-day backward simulations for 14 August 2001, 03:00 CET, initiated in the altitude range between 8000 and $8250 \mathrm{~m}$ : Column-integrated emission sensitivity, footprint emission sensitivity and retroplume summary. For details see Sect. 2.2.

\section{9, 3113-3166, 2009}

\section{High-ozone layers in} the middle and upper troposphere

T. Trickl et al.

Title Page

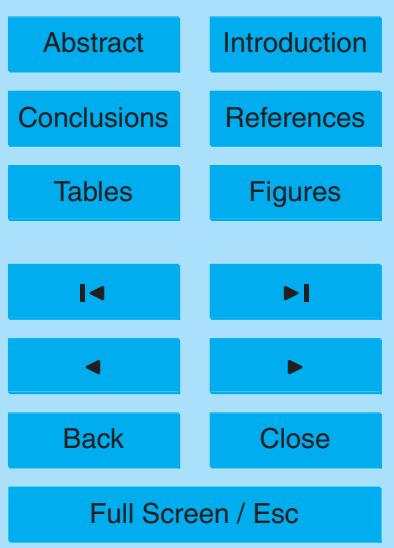

Printer-friendly Version

Interactive Discussion 